\title{
Św. Antoni Supraski
}

\author{
Antoni Mironowicz \\ Katedra Historii Europy Środkowo-Wschodniej, Uniwersytet w Białymstoku \\ Polska \\ amir@uwb.edu.pl
}

Antoni Mironowicz, St. Anthony of Suprasl, Elpis, 17 2015: 11-24.

\begin{abstract}
St. Anthony was Ruthenian and received at baptism the name of Onuphry. His relationship with the first abbot of the monastery of Suprasl Pafnucy Siehen and family Siehen suggest that he came from Bielsk. Life of a martyr from the text that is not always Onuphry lived piously. Onuphry wanted to do penance. He decided to go to the Father Pafnucy, who was abbot of the monastery of Suprasl. The young man was admitted to the monastery of the Annunciation of the Blessed Virgin Mary after 1508.

After a few years in the monastery Onuphry went to Turkey to die there for Christ. Balkan countries were occupied by the Ottoman Empire. Onuphry asked abbot Pafnucy to travel to St. Mount Athos. Pafnucy ordained Onuphry in schima, gave him the new name Anthony. Anthony, after receiving schimy and blessings from Pafnucy, went to St. Mount Athos. There lived in the tower of St. Sava Serbian.

Monk Anthony lived at the tower of St. Sava a few years. There he reached information about the martyrdom of George of Kratovo. Monk Anthony, upon hearing of the martyrdom of the young George, martyred by the Turks, decided to follow in his footsteps. To this end, the monk left St. Mount Athos and went to Thessaloniki. Upon arrival at Thessaloniki monk Anthony came to the church of the Theotokos Acheiropoietos, converted into a mosque. Antoni began to pray, made the sign of the cross and stood on his knees. This attitude of the Muslims monk found it insulting their religion, captured and subjected to torture Anthony. Kadis wanted Anthony to renounce the Christian faith. Anthony did not agree to it. Turkish judge ordered Suprasl monk burned and the ashes be scattered in the air. In this way, the Turks wanted to avoid a situation in which the body of Anthony could become an object of worship among Christians. The exact date of the martyrdom of Saint Anthony can be determined on the basis of the indirect data. Appointment of Anthony's date of death of the Julian calendar at 4 (14) February 1516 r. Day 4 February according to the Julian calendar currently corresponds to the date of February 17, according to the Gregorian calendar. February 17 was adopted as a day of remembrance of St. Anthony in the Orthodox Church.
\end{abstract}

Streszczenie: Św. Antoni był Rusinem i otrzymał na chrzcie imię Onufry. Jego powiązania z pierwszym ihumenem supraskim Pafnucym Sieheniem i rodziną Sieheniów sugerują, że pochodził z Bielska. Z tekstu żywotu męczennika wynika, że Onufry nie zawsze żył pobożnie. Onufry chciał odbyć pokutę. Onufry, zdecydował się pójść do Ojca Pafnucego, który był ihumenem monasteru supraskiego. Młodzieniec został przyjęty do monasteru Zwiastowania Najświętszej Marii Panny po 1508 r.

Po kilku latach pobytu w klasztorze Onufry udał się do Turcji by umrzeć tam za Chrystusa. Kraje bałkańskie były okupowane przez Imperium Osmańskie. Onufry prosił ihumena Pafnucego o zgodę na podróż na św. Górę Athos. Pafnucy Sieheń podstrzygł Onufrego w wielką schimę, nadał mu imię Antoni. Antoni, po otrzymaniu schimy i błogosławieństwa od ihumena Pafnucego, udał się na św. Górę Athos. Tam zamieszkał w wieży św. Sawy Serbskiego.

Po kilku latach pobytu Antoniego na Athosie do kielii św. Sawy dotarły informacje o męczeństwie Jerzego z Kratowa. Mnich Antoni, słysząc o męczeńskiej śmierci młodzieńca Jerzego, zamęczonego przez Turków, podjął decyzję pójścia jego śladami. W tym celu mnich opuścił św. Górę Athos i udał się do Salonik. Po przybyciu do Salonik mnich Antoni wszedł do cerkwi Bogurodzicy Acheiropoietos, zamienionej na meczet. Antoni Supraski zaczął się modlić, wykonał znak krzyża i stanął na kolanach. Taką postawę mnicha muzułmanie uznali za obrazę ich religii, schwytali Antoniego i poddali torturom. Kadis chciał zmusić Antoniego do wyrzeczenia się wiary chrześcijańskiej. Antoni nie zgodził się na to. Turecki sędzia polecił zakonnika supraskiego spalić a popiół rozrzucić w powietrzu. W ten sposób Turcy chcieli uniknąć sytuacji, w której ciało Antoniego mogło się stać obiektem kultu wśród chrześcijan. Dokładną datę męczeństwa św. Antoniego można ustalić na podstawie danych pośrednich. Wyznaczenie daty śmierci Antoniego według kalendarze juliańskiego na dzień 4 (14) lutego 1516 r. Dzień 4 lutego według kalendarza juliańskiego, obecnie odpowiada dacie 17 lutego, według kalendarza gregoriańskiego. 17 luty został przyjęty jako dzień pamięci św. Antoniego w Cerkwi prawosławnej.

Keywords: St. Anthony, monastery of Suprasl

Słowa kluczowe: św. Antoni, monaster supraski

Podstawowym źródłem poznania życia i męczeństwa świętego Antoniego Supraskiego jest jego żywot, który został wstawiony do rękopiśmiennego wierszowanego Proło$g u^{1}$ na miesiące wrzesień-luty. Znajdujący się na początku

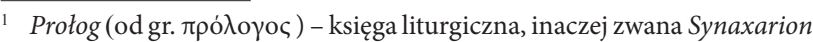
(gr. $\Sigma v v \alpha \xi \dot{\alpha} \rho\llcorner o v)$, zawierająca w zwięzłej formie żywoty świętych oraz pouczające homilie Bazylego Wielkiego, Jana Chryzostomai innych Ojców Kościoła. W słowiańskiej wersji tekstu greckiego Synaxarion został uzupełniony poprzez dodanie żywotów świętych słowiańskich. Prołog wierszowany - zawiera krótkie żywoty świętych spisane w formie wierszowanej i uzupełnione nie wierszowanym troparionem do świętego.
}

XVI wieku w monasterze supraskim Prołog został napisany około 1496 r. Prołog wrześniowo-lutowy był pierwszą częścią całorocznego kompletu wraz z wykonanym w 1496 r. Prołogiem marcowo-sierpniowym (część druga)². Oba

\footnotetext{
2 Biblioteka Litewskiej Akademii Nauk w Wilnie, Oddział Rękopisów, f. 19, nr 100. Por:: Rękopisy supraskie w zbiorach krajowych $i$ obcych, opracował Antoni Mironowicz, Białystok 2014, s. 61-62; С. Ю. Темчин, Древнейщие рукописи Супрасльского Благовещенского монастыря (1500-1532 гг.): новые данные, [в:] Современные проблемы археографии: сборник статей по материалам конференции проходивщей в Библиотеке РАН, 25-27 мая 2010 г., Санкт-Петербург 2011, с. 134.
} 
sześciomiesięczne tomy Prołogu, połączone w monasterze supraskim, zostały wykonane na zamówienie „Sołtana Sołtanowicza, namiestnika bielskiego". Namiestnikiem bielskim (1492-1494) był marszałek hospodarski (1482-1493), namiestnik słonimski (1482-1490) i nowogródzki (14861487) Sołtan Aleksandrowicz, synem podskarbiego królewskiego Aleksandra Jurewicza ${ }^{3}$. Jeżeli trzymać się werbalnie zapisu na rękopisie to prawdziwym zleceniodawcą wykonania Prołogu był najmłodszy syn Sołtana Aleksandrowicza i Wsylisy Chreptewiczówny - Aleksander Sołtanowicz, zmarły około 1554 r. ${ }^{4}$ Sołtan Aleksandrowicz zmarł bowiem w 1495 r. i zamówienia takie mógł złożyć albo jego syn, tytułowany po ojcu "namiestnikiem bielskim”, albo Sołtan Aleksandrowicz polecił wykonanie rękopisów przed swoją śmiercią. Rękopisy te zostały przekazane do monasteru supraskiego ${ }^{5}$.

H. Lulewicz, Sołtan Aleksandrowicz, „Polski Słownik Biograficzny”, t. XL, Warszawa-Kraków 2001, s. 341-343.

H. Lulewicz, Sołtan Aleksander, „Polski Słownik Biograficzny”, t. XL, Warszawa-Kraków 2001, s. 348-349.

5 W monasterze supraskim znajdowały się też inne Prołogi. Biblioteka monasterska posiadała sześciomiesięczny Prołog (wrześniowo-lutowy), który został wykonany przez grupę kopistów pod kierunkiem diakona Joachima z katedralnego soboru św. św. Borysa i Gleba w Nowogródku. Rękopis z 1512 r. został sporządzony na zamówienie metropolity Józefa Sołtana (1507-1521), który przekazał go, prawdopodobnie w 1514 r., Ławrze Supraskiej. Przed przekazaniem manuskryptu do Supraśla jego treść była sprawdzana przez wileńskiego diakona - Ignacego. Oprawę do tego tomu Prołogu wykonał mnich Porfiry z Lubczy w tym samym roku. Biblioteka Litewskiej Akademii Nauk w Wilnie, Oddział Rękopisów, f. 19, nr 95. Lubcz (Любча, Lubcza, do XIX wieku przemianowane na Lubecz) - miasteczko koło Nowogródka. Por.: А. А. Турилов, Церковно-учительная деятельность Иосифа II, „Православная энциклопедия”, т. XXVI, Москва 2011, с. 17; М. В., Чистякова, Текстология вильнюсских рукописных Прологов, Vilnius 2009. W tym samym czasie, co wspomniany wyżej sześciomiesięczny, zostały skopiowane dwa trzymiesięczne tomy Prołogu: marcowo-majowy i czerwcowo-sierpniowy. Biblioteka Litewskiej Akademii Nauk, Oddział Rękopisów, f. 19, nr-y: 98, 101; Н. А. Морозова, С. Ю. Темчин, Древнейшие рукописи Супрасльского Благовещенского монастыря (1500-1532 г2.) [w:] Z dziejów monasteru supraskiego, Supraśl-Białystok 2005, s. 129. W treść tego tomu Prołogu dodano między innymi żywoty świętych wileńskich - Jana, Antoniego i Eustachego ( $\mathrm{k}$. 491-514). Biblioteka Litewskiej Akademii Nauk, Oddział Rękopisów, f. 19, nr 95. O świętych wileńskich w tym Прологy por.: D. Baronas, Trys Vilniaus Kankiniai. Gyvenimas ir Istorija, Vilnius 2000, s. 175-181. Ten trzytomowy komplet, składający się z tomu sześciomiesięcznego i dwóch tomów trzymiesięcznych, rozpadł się, kiedy trafił do biblioteki monasterskiej na dwa kolejne trzymiesięczne tomy (wrześniowo-listopadowy i grudniowo-lutowy). Były to dwa tomy Прологу zamówione przez biskupa łucko-ostrogskiego - Makarego (1528-1534). Jego fragmenty zostały wykonane w dubieńskim monasterze przez mnicha Makarego Lwowicza z Holszan. Biblioteka Litewskiej Akademii Nauk, Oddział Rękopisów, f. 19, nr-y: 96, 97; Н. А. Морозова, С. Ю.Темчин, Древнейшие рукописи Супрасльского Благовещенского монастыря (1500-1532 г2.), s. 132-133; O pochodzeniu manuskryptu por.: Л. Л. Щавиская, Ю. А. Лабынцев, Литература белорусов Польши XV-XIX вв., Минск 2003, с. 59. Ostatecznie w Supraślu około 1530 r. z poprzednich rękopisów i dwóch nowych pozyskanych z Łucka wykonano cztery tomy Prołoga. „На весь год 4 прологи а в каждом по 3 месяцы”. Археографический сборник документов, относящихся к истории Северо-Западной Руси, издаваемьй при управлении Виленского учебного округа, т. IX, Вильна, 1870, c. 53; Biblioteka Naukowa Uniwersytetu Wileńskiego, Oddział Rękopisów, F 58-7, В 1993. k. 1 v.; Ф. Н. Добрянский, Описание рукописей Виленской публичной библиотеки, церковнославянских и русских, Вильна 1882, c. 44. Prołogi zawierały żywoty świętych i nauczania Ojców Kościoła na cały rok. Podczas dekompozycji, w celu zachowania jednorodności zbioru, z tomu grudniowo-lutowego była wyjęta ostatnia karta
Brat Sołtana Aleksandrowicza, Andruszko Aleksandrowicz Sołtan, podskarbi ziemski (1486-1498), był wielkim miłośnikiem ksiąg religijnych. W latach osiemdziesiątych XV wieku podarował on do cerkwi św. Trójcy w Wilnie Dzieje Apostolskie 6 . Z kolei innych brat Sołtana Iwan powszechnie był znany $\mathrm{z}$ zamiłowania do ksiąg i posiadania dobrego wykształcenia ${ }^{7}$.

Nas interesuje wrześniowo-lutowy Prolog wierszowany, który obecnie znajduje się w kolekcji Aleksego S. Uvarova Państwowego Muzeum Historycznego w Moskwie ${ }^{8}$. Manuskrypt został wykonany na papierze przez jednego autora, półustawem na 546 katach $^{9}$. Kodeks składa się z żywotów świętych od września do lutego ${ }^{10}$. Ten rodzaj piśmiennic-

$\mathrm{z}$ redakcji $1530 \mathrm{r}$. i dołączona do tomu czerwcowo-sierpniowego napisanego w $1512 \mathrm{r}$.

Описание Рукописного отделения Библиотеки Императорской академии наук. I. Рукописи, т. I: (I. Книги священного писания и II. Книги богослужебныя) / сост. В. И. Сперанский и Ф. И. Покровский, Санкт-Петербург 1904, с. 34; Д. Б. Кочетов, А. В. Кузьмин, Г. П. Шлевис, Виленский во имя Святой Тройцы мужсой монастырь, „Православная энцыклопедия", т. VIII, Москва 2004, с. 479; R. Cicèniené, Lietuvoc Didžiosos Kunigaištytès rankraštystès knygos kultūra (iki XVI a antroposios puses): daktaro disertacija, Vilnius 2011, s. 166. Por. o Andruszce Aleksandrowiczu, H. Lulewicz, Sołtan Andrzej, „Polski Słownik Biograficzny”, t. XL, Warszawa-Kraków 2001, s. 350-351.

H. Lulewicz, Sołtan Iwan, „Polski Słownik Biograficzny”, t. XL, Warszawa-Kraków 2001, s. 355-356.

8 Do naszych czasów zachował się XVI-wieczny oryginał drugiej części "Prologu” supraskiego ze zbiorów BAN w Wilnie znajdujący się w rękopisie Prologion Wierszowy, który jest przechowywany w Państwowym Muzeum Historycznym w Moskwie, kol. A. S. Uvarova № 56-1, k. 478-479v; Por. Арх. Леонид (Кавелин), Системаматическое описание в 4 частях, с 13 снимками ставяно-русских рукописей собрания графа А. С. Уварова, ч. II, Москва 1893, с. 320; Н. Ф. Бельчиков, Ю. К. Бегунов, Н. П. Рождественский, Справочник-указатель печатных описаний славяно-русских рукописей, Москва 1963, с. 157-159. Na jego temat pisali między innymi: А. А., Турилов, Антоний Супрасльский, „Православная энциклопедия", т. 2. Москва 2000, с. 680; С. Ю. Темчин, Древнейшие рукописи Супрасльского Благовещенского монастыря (1500-1532 г2.): новые данные, [w:] Современные проблемы археограбии: Сборник статей по материалам конференции, проходивщей в Библиотеке РАН, 25-27 мая 2010 2., (ред. И. М. Беляева), Санкт-Петербург 2011, с. 134; М. В. Чистякова, Текстологические особенности стишного пролога ГИм, Увар. 56. - „Kalbotyra 55(2). Slavistica Vilnensis

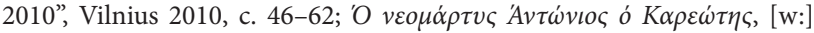

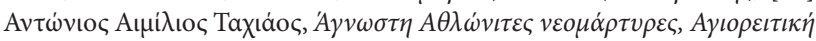
$\beta \iota \beta \lambda \iota 0 \theta \dot{\eta} \kappa \eta$, 'Aүıо 'Opoৎ 2006, s. 11-49.

Rękopis posiada oryginalną oprawę, deskę w skórze o wymiarach 246x185 milimetrów. Skóra z tłoczeniem, na brzegach wielowarstwowa geometryczna ramka $\mathrm{z}$ roślinnym i kwiatowym wypełnieniem, w centrum roślinny ornament $\mathrm{w}$ formie rombu (obie okładziny), na górnej okładzinie na dole i na górze wytłoczono ruską ligaturą книга Г̈Аємата, na górnej okładzinie zachowały się oba mocowania od zapięć, na tylnej okładzinie oba zapięcia z tłoczeniem, brzeg pomalowany na ciemny kolor, skórzany grzbiet w kolorze zielonym - wtórny, podklejony w XIX w., na nim złotymi literami wytłoczono: 56, ПРОЛОГЪ, herb $\mathrm{z}$ inicjałami „А(лексей) У(уваров)".

10 Tekst $\mathrm{w}$ jednej kolumnie, 30 wierszy na karcie, paginacja kart na pierwszej i ostatniej karcie zeszytu, łącznie 69 zeszytów, w ostatnim zachowało się 5 kart, nagłówek późniejszy niedbałym charakterem pisma ze wskazaniem miesiąca i dnia. Na k. 1v. uwagi czytelnicze atramentem, skoropisem o tematyce niektórych prologowych pouczeniach na wrzesień, grudzień, styczeń; na k. 455, 456-456v. - czytelnicze marginalia półustawem, cyno-

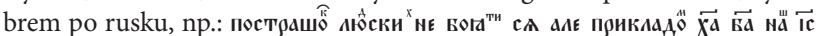

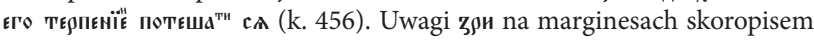
atramentem. W tekście znajdują się iluminacje (k. 1: zastawka w stylu bałkańskim, kontur wypełniony cynobrem, ruska ligatura, średnie inicjały z ozdobnymi pędami roślinnymi, małe cynobrowe inicjały, nagłówki 
twa hagiograficznego był na obszarze słowiańskim wzorowany na greckim Mívoגoyiov, księdze opracowanej w latach panowania cesarza Bazylego $\mathrm{II}^{11}$.

Prolog zawiera krótkie żywoty świętych na każdy dzień roku liturgicznego wraz $\mathrm{z}$ troparami spisanymi w formie wierszowanej i kilka pouczeń. Supraska redakcja Prologu stanowi kompilację prologu wierszowanego redakcji bułgarskiej i nowogrodzkiej oraz kilku innych redakcji prologu prostego (bez wierszowanych troparionów). Prolog zawiera żywoty świętych Borysa i Gleba (5 września), księżniczki czeskiej Ludmiły (16 września), św. Michała, księcia czernihowskiego (20 września), św. Sergiusza z Radoneża (25 września), księcia czeskiego Wiaczesława (28 września), św. Paraskiewy (13 października), św. Mikołaja Światosławowicza z Czernihowszczyzny, błogosławionego Jana Rylskiego (19 października), opowiadania o przeniesieniu relikwii św. Hilariona (21 października), arcybiskupa serbskiego Arseniusza, św. Sawy Serbskiego (12 stycznia) i jego ojca Symeona (13 lutego $)^{12}$. Prolog wierszowany na wrzesień-luty kończy się żywotem męczennika Proteriusza (28 luty). Do żywotów znanych świętych dodano biografie świętych metropolitów moskiewskich Piotra i Aleksego oraz innych dziesięciu „podwiżników” z Ławry Kijowsko-Pieczerskiej. Tak więc Prolog supraski zawiera żywoty świętych z Rusi Kijowskiej, świętych z Bałkanów i Rusi Moskiewskiej, Czech i Moraw oraz z niektórych żywotów świętych z Cerkwi Bizantyjskiej ${ }^{13}$. Wymienione powyżej teksty zostały spisane w latach osiemdziesiątych $\mathrm{XV}$ wieku. Żywot świętego Antoniego Supraskiego zo-

i rubrykacja cynobrem, na k. 1v tekst zakończony dekoracyjnym lejkiem) i filigrany (znak wodny: głowa byka z 5-płatkowym kwiatkiem, z tarczą na podbródku ident. - Piccard: rБ-XII № 798 z 1494 r. Na dodanych kartkach 478-479 znak wodny: dzik - ident.: Piccard: Кабан-XV № 98 z 1541 r.) Stan zachowania rękopisu: skóra na górnej okładzinie przetarta, górna część grzbietu porwana, przednia i tylna deska odpada od bloku, rękopis mocno zabrudzony, zawilgocony, zalany woskiem, ze śladami rdzy, część kart podklejona, w wielu przypadkach z utratą tekstu; k. 424 przepalona; karty: 391, 455, 465, 470 naderwane. Rękopis znajdował się w bibliotece monasteru supraskiego do 1877 r., skąd trafił do Wileńskiej Biblioteki Publicznej. W 1915 r. manuskrypt został ewakuowany do Moskwy, gdzie znajduje się do dziś w Państwowym Muzeum Historycznym.

11 Н. Д. Буднов, „Славянские Прологи”, Методологическое пособие по описании славянию-русских рукописей для Сводного каталога рукописей, хранящихся в СССР, выпуск I, Москва 1973, с. 274-296; Славянские рукописи Афоних обителей (сост. А. А. Турилов и Л. В. Мошкова), под ред. А.Э.Н. Тахиоса, Фессалоники 1999, с. 164-165, 230-234; А. А. Турилов, К истории Стишного Пролога на Руси, „Древняя Русь. Вопросы Медиевистики", нр. 1 (23), март 2006, с. 70-75; Г. Петков, Стишнят Пролог в старата бъларска, сръбска и руска литература $X I V-X V$ в., „Археография, текстология и издание на проложни стихове”, Пловдив 2000, с. 143-190; 467-520.

12 А. А. Турилов, Южнославянские памятники в литературе и книжности Литовской и Московской Руси XV- первой половины XVI в.; парадоксы истории и географии культурных связей, „Славянский

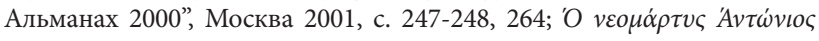

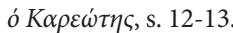

Ю. С. Самодурова, Редакиионная принадлежность бельского Стишного пролога (на март-август) 1496 г., „Studia Historica Europae Orientalis. Исследования по истории Восточной Эвропы", вып. 3, 2010, с. 255-264; М. В. Чистякова, Текстологические особенности стишного пролога ГИМ, Увар. 56, „Slavistica Vilniensis: Kalbotyra”, vol. LV(2), 2010, s. 46-62. stał wstawiony do rękopisu na k. 478-479 w latach 1540$1541^{14}$.

Po raz pierwszy na to źródło zwrócił uwagę moskiewski badacz Anatol Turiłow w swych publikacjach z 2001 r. $^{15}$ W ostatnim czasie ukazały się trzy krótkie monografie poświęcone św. Antoniemu Supraskiemu autorstwa wspomnianego wyżej Anatola Turiłowa, Antoniosa Tachiaosa, Antoniego i Marcina Mironowicza ${ }^{16}$. Pośrednio o św. Antonim Athoskim (Supraskim) wspominali inni autorzy ${ }^{17}$.

Żywot św. Antoniego Supraskiego rozpoczyna się słowami: „Сей русин бяше родом, христиану родителю сын, от юности святаго крещения прием благодать и божественным наказався письменем, сурово и в буести юность превождая” a kończy: „палицею железною в главу ударив, посреде огня паднути сотвори мученика, и толико сожгоша его, яко и пепел на воздух развеяти, да не возмут христиане останкы телесе его”. Do żywotu świętego dodano wiersz „Христовы любве разжегся Антоние огнем, чувственнаго жжения не устрашися огня. Прохлаждение небесное прием Антонии в четвертыи”. Krótki „hymn” przed żywotem to tzw. stich-stychos, który poprzedza synaksarion (żywot świętego, bądź opis święta). Tego typu bardzo krótkie wierszowane strofy pojawiają się we wszystkich synaksarionach przeznaczonych do liturgicznego czytania po szóstej pieśni kanonu, po kondakionie i ikosie. W epoce bizantyjskiej stychosy były często pisane starogreckim językiem literackim, o wiele bardziej kunsztownym od zwykłej bizantyjskiej greki liturgicznej.

Żywot św. Antoniego Supraskiego spisano w jednym

14 А. А. Турилов, Южнославянские памятники в литературе и книжности..., с. 256; Rękopisy supraskie w zbiorach krajowych i obcych, opracował Antoni Mironowicz, Białystok 2014, s. 320.

15 А. А. Турилов, Антоний Супрасльский, „Православная энциклопедия”, т. II, Москва 2001, с. 680; А. А. Турилов, Южнославянские памятники в титературе и книжности Литовской и Московской Руси XV - первой половины XVI в.: парадоксы истории и географиикультурных связец̆, „Славянский альманах 2000”, Москва 2001, с. 275, прм. 81 .

16 А. А. Турилов, Житие преподобномученика Антония Супрасльского и славянские жития балканских новомучеников XVI в. (к постановке проблемы), „Hagiographia Slavica”, ed. Herausg. von J. Reinhart, Munchen-Berlin-Wien 2013, (Wiener Slawistischer Almanach.

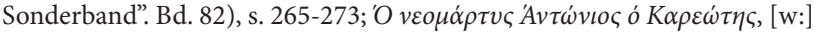

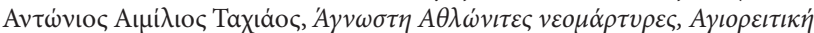

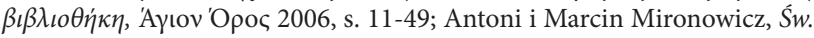
Antoni Supraski, Białystok 2014.

В. И. Григорович-Барский, Очерк путешествия по Европейской Туриии, Казань 1848; tenże, Первое посещение Св. Афонской горы, Санкт-Петербург 1884; tenże, Второе посещение Святой горы, Санкт-Петербург 1887; tenże, Три древних сказания о Св. горе Абонской и краткое описание Св. Горь, Москва 1895; А. Соловјев, Св. Сава u Pуси, „Српски Кœижевни Гласник. Нова серия”, т. XXXXIV, Београд 1935, № 3, с. 221-225; М. Н. Тихомиров, Исторические связи русского народа с южными славянами с древнейших времен до половины XVII в., „Славянский сбобор”, Москва 1947, с. 164, 170-171, 174, 181-183, 191, 193, 199-200; Сава Хиландараи. Историја манастира Хиландара, Београд 1997; Петр (Пиголь), игум., Преп. Григорий Синаит и его духовные преемники, Москва 1999; Осам векова Хиландара: историја, духовни живот, коижевност, уметност и архитектура, Београд 2000; А. Фотич, Света Гора и Хиландар у Османском иарству, XVXVII в., Београд 2000; Н. Н. Бантыш-Каменский, Реестры греческим делам Московского архива Коллегии иностранных дел, Москва 2001. 
z klasztorów athoskich na podstawie opowieści mnichów. Żywot ten był znany mnichom supraskim, albowiem wielu zakonników ze Świętej Góry Athos przebywało w prawosławnych ośrodkach monastycznych na terenie Wielkiego Księstwa Litewskiego. Dodanie do XV-wiecznego Prołogu żywotu św. Antoniego Supraskiego wskazuje na to, że postać męczennika wśród mnichów budziła powszechny szacunek. Świętego supraskiego dołączono do grona świętych z poprzednich stuleci, którzy w swych krajach obdarzeni byli powszechnym kultem. Autor ostatecznej wersji kodeksu pragnął nadać nowemu męczennikowi rangę równą świętym czeskim, serbskim czy moskiewskim ${ }^{18}$.

Język tekstu żywotu św. Antoniego wskazuje na to, że został on napisany przez mnicha z ziem ruskich, który nie posiadał dobrego kunsztu literackiego. Autor dodatku do Kodeksu znajdował się pod wpływem piśmiennictwa bułgarskiego. Częste używanie samogłoski dźwięcznej и (ж) oznacza wyraźny wpływ języka bułgarskiego ${ }^{19}$. Na tej podstawie możemy stwierdzić, że pochodzący prawdopodobnie z Wołynia bądź Podlasia autor żywotu św. Antoniego Supraskiego albo przebywał na Świętej Górze Athos w bułgarskim monasterze ochrydzkim, albo oparł się na starszej bułgarskiej wersji zapisu hagiograficznego, która trafiła na ziemie ruskie. Występowanie rękopisów bułgarskich na terenie Wielkiego Księstwa Litewskiego w XV i XVI stuleciu było zjawiskiem dość częstym. Niestety, nie posiadamy żadnego dowodu na istnienie wcześniejszego bułgarskiego oryginału żywotu świętego męczennika supraskiego. W tej sytuacji należy przyjąć, że jego anonimowy autor - Rusin sam przebywał w monasterze na Górze Athos, gdzie znajdowały się księgi napisane w języku bułgarskim i tam poznał losy Antoniego Supraskiego.

Bliższa wydaje się być inna wersja, że twórcą żywotu św. Antoniego był mnich supraski Arseniusz, który trafił do monasteru serbskiego w Chilandarze po 1536 r. W 1530 r. mnich supraski Arseniusz, były duchowny Aleksy, skopiował pracę św. Jana Klimaka Лествица. Книга Лествииа в полдесть znajdowała się $\mathrm{w}$ monasterze przed $1530 \mathrm{r}$. W wyniku powstałego konfliktu z archimandrytą Sergiuszem Kimbarem ${ }^{20}$, hieromnich Arseniusz zabrał skopiowaną przez siebie pracę św. Jana Klimaka Лествийa i udał się do serbskiego monasteru Chilandar na św. Górze Athos ${ }^{21}$.

\footnotetext{
18 Zupełnie nieuprawniony jest pogląd Anatola Turiłowa, że kult jego nie był akceptowany przez Cerkiew z uwagi na fakt spalenia ciała męczennika, co pozbawiało wiernych obiektu czci oraz z uwagi na dwuznaczny sens dobrowolnego męczeństwa, które w istocie było formą samobójstwa, potępianego przez Cerkiew. А. А. Турилов, Житие преподобномученика Антония Супрасльского и славянские жития балканских новомучеников XVI в. (к постановке проблемы), с. 271.

19 Е. Ф. Карский, Славянская кирилловская палеография, Ленинград 1928, c. 174-175.

20 A. Mironowicz, Ewangelizacja „prosta mowa” w XVI wieku, „Latopisy Akademii Supraskiej”, vol. III, pod red. U. Pawluczuk, Białystok 2012, s. 9-18.

21 O supraskim pochodzeniu manuskryptu informuje nas zapis na jego 275 stronie. „В лето 7038 (1530), индикта 3, списана бысть книга Лествичникь у монастыри общомь в обители Благовещениа пресвятыя Богородица и святаго Иоанна Богослова иже на реци Супрасле, желаниемь и рукою многогрешнаго инока Арсениа, бывшаго вь мирском житии Алексеа недостоинаго попа". Katalog biblioteki rękopisów monasteru serbskiego Chilandar, nr 185; Д. Богданович, Каталог кирил-
}

Arseniusz słysząc o męczeństwie schimnika Antoniego mógł uwiecznić jego żywot i odesłać do monasteru supraskiego. I choć teza ta nie ma potwierdzenia źródłowego znajduje swoje uzasadnienie we wspólnym pochodzeniu obu mnichów, pobycie w tym samym serbskim klasztorze na Athosie oraz następstwie czasowym. Arseniusz trafił do Chilandaru w II połowie lat trzydziestych XVI wieku a żywot św. Antoniego powstał przed 1540 r. by zostać dołączonym do supraskiego „Prologu” w roku następnym.

\section{Życie i męczeństwo św. Antoniego Supraskiego}

Św. Antoni, jak informuje nas biograf, był Rusinem i otrzymał przy wstąpieniu do monasteru imię zakonne Onufry ${ }^{22}$. Według niektórych badaczy późniejszy męczennik był mieszkańcem Wołynia lub Rusi Halickiej23. Jednakże jego powiązania z pierwszym ihumenem supraskim Pafnucym Sieheniem i rodziną Sieheniów sugerują, że św. Antoni pochodził z Podlasia, prawdopodobnie z Bielska. $\mathrm{Z}$ żywotu męczennika można wywnioskować, że wywodził się on z prawosławnej rodziny mieszczańskiej. Biograf podaje, że przyszły mnich Onufry był dobrze wykształcony,

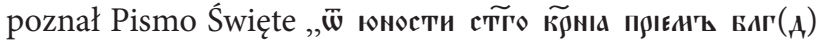

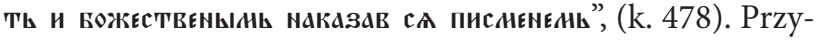
toczony fragment pozwala przypuszczać, że Onufry uczył się w młodości w szkole przycerkiewnej. W szkole tej litery, które poznawał, były uważane za święte, a teksty były czytane w Cerkwi.

Z tekstu żywotu męczennika wynika, że Onufry nie zawsze żył pobożnie, jak starano się wychowywać go $\mathrm{w}$ rodzinie. Znany był z nadmiernej pobudliwości, co doprowadziło go do zabójstwa człowieka. Jego wychowanie religijne było jednakże na tyle silne, że w duszy potępił swój postępek. Obudziły się w nim normy chrześcijańskiej moralności i poczucie głębokiej winy. Stan taki doprowadził Onufrego do szczerej modlitwy, przemyślenia swego świeckiego życia, skruchy i chęci odbycia pokuty. Dążenie do oczyszczenia duszy i chęć naprawienia winy spowodowało, że młody Podlasianin zdecydował się odbyć pokutę przez całą resztę swego życia. „Ð̈)

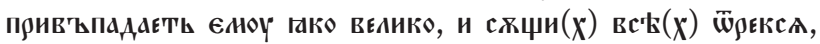

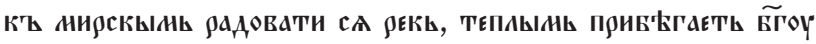
покаaнiz(м)", (k. 478).

Hagiograf podaje, że Onufry, będąc w takim stanie

ских рукописа манастира Хиландара, Београд 1978, с. 104; Славянские рукописи Абонских обителей, составили: А. А. Турилов і Л. В. Мошкова, под редакцией А. Э. Н. Тахиоса, Фессалоники 1999, с. 127; Л. Л. Щавиская, Ю. А. Лабынцев, Литература белорусов Польши XV -XIX вв., c. 61, 111, przyp. 36; Por.: Rękopisy supraskie $w$ zbiorach krajowych i obcych, opracował Antoni Mironowicz, Białystok 2014, s. 73, 370-371.

22 А. А. Турилов, Антоний Супрасльский, „Православная Энциклопедия”, т. II, Москва 2000, с. 680; J. Charkiewicz, Św. Antoni Supraski, „Wiadomości Polskiego Autokefalicznego Kościoła Prawosławnego”, nr 3(184), 2005, s. 11; Por.: Wydanie okolicznościowe żywotu świętego z ikoną św. Antoniego Supraskiego, Supraśl 2007.

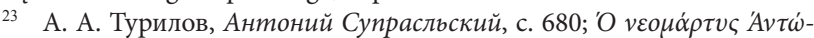

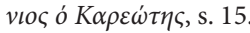


ducha, zdecydował się pójść do Ojca Pafnucego, który był mężem błogosławionego życia i ihumenem założonego przez siebie monasteru supraskiego. „И к' Пафн४тію

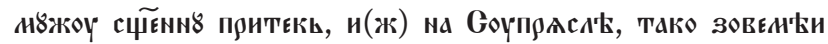

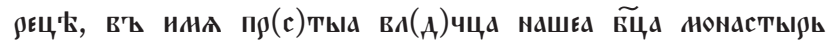

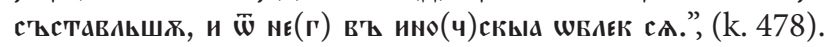
Młodzieniec został przyjęty do monasteru Zwiastowania NMP. Z przytoczonego fragmentu wynika, że wstąpił on do jeszcze budującego się nad rzeką Supraśl monasteru. Wzmianka ta pozwala na ustalenie roku przybycia Onufrego do monasteru. $\mathrm{Z}$ pewnością nastąpiło to po przeniesieniu monasteru z Gródka na uroczysko Suchy Hrud nad rzeką Supraśl. Przybycie do budującego się monasteru mogło nastąpić po $1508 \mathrm{r}$. Wobec panującego na terenie Wielkiego Księstwa Litewskiego oficjalnego zakazu budowy cerkwi murowanych, wymagana była zgoda królewska na wzniesienie takiej świątyni. Ihumen Pafnucy Sieheń wystąpił z taką prośbą do króla na początku $1509 \mathrm{r}$. W połowie marca 1509 r. Zygmunt Stary wyraził zgodę na wybudowanie murowanej cerkwi ${ }^{24}$. Dopiero po uzyskaniu takiej zgody można było przystąpić do zaplanowanej inwestycji. Rozpoczęto ją w październiku 1510 r. W 1509 r. i w pierwszych dziewięciu miesiącach roku następnego gromadzono materiały.

Ihumen Pafnucy Sieheń cieszył się powszechnym autorytetem $\mathrm{z}$ uwagi na swe pobożne życie oraz ogromne wysiłki poniesione przy założeniu i wybudowaniu monasteru. Patriarcha konstantynopolitański Joachim (1498-1502; $1504)^{25}$ przesłał ktitorom monasteru: biskupowi smoleńskiemu Józefowi Sołtanowi i Aleksandrowi Chodkiewiczowi tomos, który dotarł do adresata w 1505 r. Tomos ustanawiał regułę monastyczną o ustroju cenobitycznym ${ }^{26}$. Monaster supraski po 1505 r. został wyjęty spod jurysdykcji metropolity kijowskiego i podporządkowany bezpośrednio patriarsze. Status monasteru został potwierdzony na synodzie wileńskim w 1509 r. Przebywający na nim hieromnich Filip z Konstantynopola oraz ihumen supraski Pafnucy byli oficjalnymi reprezentantami patriarchy carogrodzkiego ${ }^{27}$.

\footnotetext{
24 AP w Krakowie, AMCh, sygn. 36, nr 29; Николай (Далматов), Cyпрасльский Благовещенский монастырь, Санкт-Петербург 1892, с. 45; А. Белецкий, Митрополить Іосифг II Солтанъ и отночение его къ Супрасльскому монастырю, Вильна 1899, с. 21; Модест (Стрельбицкий), Супрасльский Благовещенский монастырь, «Вестник Западной России», т. I, кн. 2, Вильно 1867, с. 75; Ф. Покровский, Археологическая карта Гроденской губерни, Вильна 1895, с. 72; Summariusz dokumentów do dóbr supraskich, opr. A. Mironowicz, Białystok 2009, s. 55; A. Mironowicz, O początkach monasteru supraskiego i jego fundatorach, Supraśl 2013.

25 G. Podskalsky, Griechische Theologie In der Zeit der Türkenherrschaft (1453-1821): die Orthodoxie im Spannunsgsfeld der nachreformatischen Konfessionen des Westens, München 1988, s. 398.

${ }_{26}$ Документы относящиеся к истории православия в Западной Руси, „Вестник Юго-Западной и Западной России”, Г. V, 1867, кн. 1, т. I, отд. 1, c. 1-5. Cenobium: klasztor lub skit, gdzie mnisi cenobici prowadzą życie wspólnotowe, modląc się, jedząc i pracując razem. Cenobityczna forma

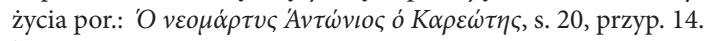

27 Митрополит Макарий, История Русской Церкви, кн. V, Москва 1996, c. 100-101, 117; A. Mironowicz, Sobory wileńskie 1509 i 1514 roku, („Synody Cerkwi Prawosławnej w I Rzeczypospolitej”). „Latopisy Akademii Supraskiej”, vol. V, pod red. M. Kuczyńskiej i U. Pawluczuk, Białystok 2014, s. 71-82.
}

Monaster już wówczas był znanym prawosławnym ośrodkiem intelektualnym, posiadał bogate zbiory rękopisów ${ }^{28}$, $\mathrm{w}$ tym najstarszy zabytek piśmiennictwa cerkiewnosłowiańskiego Минея четья pochodzący z początków XI stulecia ${ }^{29}$.

Do tego monasteru przybył Onufry. Opiekę duchową nad nim przejął znajomy mu lub jego rodzicom ihumen Pafnucy Sieheń. Onufry został przyjęty jako nowicjusz, odziany $\mathrm{w}$ rasę z prostego sukna. Po wstąpieniu do monasteru Onufry prowadził życie zgodnie z klasztornym typikonem $^{30}$, wzorowo uczęszczał na nabożeństwa i wypełniał poleceniami przełożonego. Typikon supraski był surowy i wprowadzał cenobityczne zasady życia wewnętrznego. Nawiązywał on do typikonów monasterów ze Świętej

28 Николай (Далматов), Супрасльский Благовещ,енский монастырь, с. 54-61; Ф. Н. Добрянский, Описание рукописей Виленской публичной библиотеки, иерковнославянских и русских, с. XXVII-XXXIII; М. Грушевський, Історія України Руси, т. VI, Київ-Львів 1907, с. 338-340; А. И. Рогов, Супрасль как один из центров культурных связей Белоруссии с другими славянскими странами, [в:] Славяне в эпоху феодализма, Москва 1978, с. 321-334; С. Ю.Темчин, Сколько книг было в Супрасльском Благовещенском монастыре в 1532 году, „Здабыткі”, вып. 12, Мінск 2010, с. 68-75; tenże, Рукописи Кимбаровского собрания Супрасльского Благовещенского монастыря (1532-1557 г2.), „Knygotyra”, t. LIV, Vilnius 2010, s. 173-180; E. Laucevičius, XV - XVIII a. knygu įrišimai Lietuvos bibliotekose, Vilnius 1976; Н. А. Морозова, С. Ю.Темчин, Древнейшие рукописи Супрасльского Благовещенского монастыря (1500-1532 г2.), [w:] Z dziejów monasteru supraskiego, Supraśl-Białystok 2005, s. 117-140; Ю. А. Лабынцев, Православная Академия Ходкевичей и ее издания, Минск 1996, с. 151-158; Л. Л. Щавиская, Литературная культура белорусов Подляшья XV-XIX вв., Книжые собрания Супрасльского Благовещенского монастьря, Минск 1998; Л. Л. Щавиская, Ю. А. Лабынцев, Литература белорусов Польши XVXIX вв., Минск 2003; А. Mironowicz, Biblioteka monasteru supraskiego w XVI wieku, „Białoruskie Zeszyty Historyczne”, nr 36, Białystok 2011, s. 5-23; А. Миронович, Библиотека Супрасльского монастьря в XVI веке, [w:] Rediscovery. Bulgarian Codex Supraslienis of 10th century, ed. A. Miltenova, Sofia 2012, s. 309-329.

29 „Книг великих в десть соборников 4, а пятый на паркгамене”. Л. Л. Щавинская, Литературная культура белорусов Подляшья $X V$-XIX вв., с. 78, 127, прим. 4. „Kodeks supraski - najstarszy zabytek piśmiennictwa cyrylickiego został wydany w formie reprintu w Bułgarii. Супрасълски или Ретков сборник, Й. Заимов, увод и коментар на старобългарски текст, М. Капалдо, подбор и коментар на гръцкия текст, т. I, София 1982, т. II, София 1983; Л. Стефова, Супрасълски сборник, [в:] Кирило-Методиевска енииклопедия, ред. Л. Грашева, т. III, София 2003, с. 776-784. Według najnowszych ustaleń rękopis ten powstał w połowie X wieku (941 r.) na terenie Bułgarii. G. Krustev, A. Boyadjiev, On the Dating of Codex Suprasliensis, [w:] Rediscovery. Bulgarian Codex Supraslienis of 10th century, ed. A. Miltenova, Sofia 2012, s. 17-23. Pogląd ten pozostaje jednakże w formie hipotezy badawczej i nie stanowi ostatecznych ustaleń. Por. również: C. Ю. Темчин, О бытовании древнеболгарского Супрасльского сборника в Великом княжестве Литовском в XV-XVI вв., [в:] Этнокультурные и этноязыковые контакты на территории Великого княжества Литовского. Материаль международной научной конференичи, Москва 2006, с. 174-189; tenże, Бbтование древнеболгарского Супрасльского сборника в Великом княжестве Литовском в XVI-XVII веках: новые данные, [w:] Rediscovery. Bulgarian Codex Supraslienis of 10th century, ed. A. Miltenova, Sofia 2012, s. 195-215. A. Kaszlej, Dzieje kodeksu supraskiego, Supraśl 1997, s. 22; A. Mironowicz, Kodeks supraski, „Białostocczyzna” 1988, nr 1(9), s. 1-3; E. Kierejczuk, Kodeks supraski wśród zbiorów biblioteki monasteru supraskiego. Kilka hipotez w sprawie czasu przybycia Minieji Czetnej z XI wieku do Supraśla, „Latopisy Akademii Supraskiej”, pod red. U. Pawluczuk, vol. II, Białystok 2011, s. 141-150.

30 Typikon, od greckiego słowa typicon - oznacza statuty redagowane przez przełożonego monasteru, w których ustalone są przepisy dotyczące życia wewnętrznego klasztoru i obowiązków mnichów. 
Góry Athos. Patriarcha upominał monastery athoskie, ażeby prowadziły życie cenobityczne. $\mathrm{W}$ tym bowiem czasie dominowała na Górze Athos tendencja do anachorycznej formy życia zakonnego (w samotności) ${ }^{31}$.

Onufry, pragnąc odpokutować swe grzechy, powziął zamiar udania się do krajów „agarańskich”32, by umrzeć tam za Chrystusa. Mianem kraju agarańskiego (bisurmańskiego) określano wówczas Turcję i kraje bałkańskie okupowane przez Imperium Osmańskie. Na tym terenie wielu chrześcijan poniosło męczeńską śmierć z rąk Turków. Powstaje pytanie - skąd mnich Onufry wiedział o nowych męczennikach i sytuacji chrześcijan pod okupacją turecką? Wielkie Księstwo Litewskie utrzymywało liczne kontakty z krajami bałkańskimi, o czym świadczy duża liczba zabytków piśmiennictwa bułgarskiego i serbskiego na jego terenie $\mathrm{z}$ tego okresu ${ }^{33}$. Monaster supraski utrzymywał bliskie więzi z athoskimi, serbskimi i bułgarskimi ośrodkami klasztornymi. Informację o prześladowaniu chrześcijan przez Turków Onufry mógł uzyskać od osób przybyłych z Bałkanów do monasteru supraskiego ${ }^{34}$.

Onufry uznał, że najpełniej oczyści się ze swojego grzechu, jeżeli umrze za wiarę. Mnich znał też przypadek oczyszczenia z grzechu poprzez męczennictwo z 1347 r., kiedy to trzej ochrzczeni przez mnicha Nestora rycerze zostali zamordowani na rozkaz księcia litewskiego Olgierda $^{35}$. Męczeństwo świętych Antoniego, Jana i Eustachego

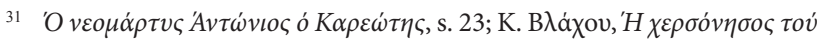

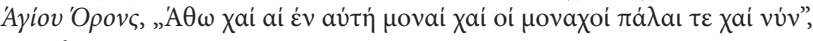
غ́v Bó $\lambda \omega$ 1903, s. 83-91.

32 Terminem tym nazywano kraje islamskie od Agar - służącej i nałożnicy Abrahama. Od niej miały pochodzić plemiona arabskie i tureckie. Agaranie - plemię koczownicze w Azji Mniejszej postrzegane jako „wrogowie Boga”. Z czasem nazwa potomków Agary i plemienia Agaranów została rozciągnięta na kraje tureckie i tatarskie lub zajęte przez Imperium Otomańskie.
}

33 Я. Н. Щапов, Восточнославянские и южнославянские рукописные книги в собраниях Польской Народной Республики, Москва 1976, с. 54-64; А. И. Рогов, Литературные связи Белоруссии с балканскими странами в XV-XVI вв., [в:] Славянские литературы. VIII Международный съезд славистов, Загреб-Любляна, сентябрь 1978 г. Докладь советской делегации, Москва 1978, с. 188, 190-194.

34 A. Mironowicz, Supraśl jako ośrodek kulturalno-religijny w XVI wieku, Leiman 1984; tenże, Związki literackie Kijowa $z$ monasterem supraskim $w$ XVI wieku, „Slavia Orientalis”, t. XXXVIII, nr 3-4, 1989; tenże, Podlaskie ośrodki i organizacje prawosławne w XVI i XVII wieku, Białystok 1991; tenże, Tożsamość i tolerancja $w$ rozumieniu prawosławnych zakonników supraskich w XVI wieku, „Rocznik Teologiczny”, R. XL, z. 1-2, Warszawa 1998; tenże, Życie monastyczne na Podlasiu, Białystok 1998; Oddziaływanie kultury ruskiej na życie duchowe zakonników monasteru supraskiego w XVI wieku, [w:] Oblicza wschodu w kulturze polskiej, pod. red. G. Kotlarskiego i M. Figury, Poznań 1999, s. 405-414; tenże, Literatura bizantyjska w Kościele prawosławnym na terenie Wielkiego Ksiestwa Litewskiego w XVI wieku, „Търновска Книжовна Школа”, Търново и идеята за Християнския Универсализъм XII-XV век, т. IX, Велико Търново 2011, с. 692-704; tenże, Związki monasteru supraskiego ze Świętą Górą Athos w XVI wieku, [w:] Święta Góra Athos w kulturze Europy. Europa $w$ kulturze Athos, pod red. M. Kuczyńskiej, Gniezno 2009, s. 122-134.

35 J. Meyendorff, The Three Lithuanian Martyrs: Byzantium and Lithuania in the Fourteenth Century, „Eikon und Logos. Beiträge zur Erforschung byzantinischer Kulturtraditionen", Band 2, Halle 1981, s. 179-197; A. Mironowicz, Kościół prawosławny w państwie Piastów i Jagiellonów, Białystok 2003, s. 77, 139. było powszechnie znane na terenie Wielkiego Księstwa Litewskiego, w tym i w monasterze supraskim. Męczeństwo świętych wileńskich było znane na terenie Bizancjum. Na prośbę patriarchy carogrodzkiego Filoteusza Czerwonego (1354-1355, 1364-1376), przyszły metropolita kijowski Cyprian przywiózł w 1374 r. fragmenty relikwii świętych wileńskich do Konstantynopola. Z polecenia patriarchy w Salonikach Michał Balsanovos (Mıхań $\lambda$

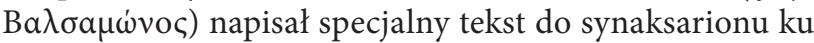
czci świętych wileńskich ${ }^{36}$. Po upadku Cesarstwa Bizantyjskiego, staraniem metropolitów kijowskich, relikwie męczenników powróciły w końcu XV wieku z powrotem do Wilna a część w relikwiarzach zawieziona została na Ruś Moskiewską ${ }^{37}$.

Tradycja męczeństwa za Chrystusa na terenie Wielkiego Księstwa Litewskiego była ciągle żywa. Można więc założyć, że Onufry, naśladując męczenników wileńskich, pragnął oddać życie za wiarę w ten sam sposób: $\mathrm{z}$ rąk rządzących, którzy nie byli prawosławnymi. W tym czasie Wielkie Księstwo Litewskie oficjalnie stało się krajem katolickim, ale nie było w nim takiego prześladowania prawosławnych, jak w państwach bałkańskich. Do monasteru supraskiego napływały informacje o kolejnych męczennikach, którzy zginęli z rąk Turków.

Onufry, ogarnięty wielkim zapałem, zwrócił się do przełożonego monasteru, ażeby ten pozwolił mu udać się do agarańskich krajów. „Мч Чнчствва(жє) привохоА ...

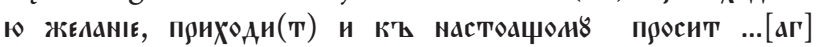
арАнскЫ(д) странань шествІє неночно в...цно.", (k. 478). Ihumen Pafnucy zabronił mnichowi opuszczenia monasteru i poradził mu, „aby wyczekiwał cierpliwie i w spokoju łaski Boga". Po zdecydowanej odmowie przełożonego monasteru, Onufry prosił ihumena Pafnucego, aby mógł udać się na Świętą Górę Athos, by tam porozmawiać na temat swojego zamysłu z pobożnymi mnichami. Pafnucy Sieheń uświadomił sobie, że trudno będzie zatrzymać młodego i gorliwego mnicha, więc przyjął inne rozwiązanie. W tajemnicy przed ogółem braci zakonnej zaprosił on kilku starszych mnichów i podstrzygł Onufrego w wielką schimę, nadając mu imię Antoni. Równocześnie ihumen dał Antoniemu zgodę na wyjazd na Świętą Górę Athos

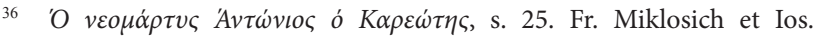
Müller, Acta Patriarchatus Constantinopolitani, vol. I, Vindobonae 1860, s. 523-524; D. Baronas, Trys Vilniaus Kankiniai. Gyvenimas ir Istorija, s. 200-243; Д. Баронас, По поводу титературной истории Мучения трех виленских мучеников, "Krakowsko-Wileńskie Studia Slawistyczne”, t. III, pod red. W. Stępniak-Minczewej, A. Naumowa, Kraków 2001, s. 78, 98; Б. Н. Флоря, Г. Шлевис, Я. Э. Зеленина, Антоний, Иоанн и Евстафий, „Православная энциклопедия”, т.XI, Москва 2001, c. 666-668. Synaksarion, synaksariusz (gr. $\Sigma v v \alpha \xi \alpha ́ \rho ı$, od słowa $\sigma v v \alpha \gamma \varepsilon \iota v$ - zbierać razem) - księga, zawierająca krótkie życiorysy świętych na każdy dzień roku liturgicznego (w roku przejściowym).

37 А. И. Рогов, Литературные связи Белоруссии с балканскими странами в XV-XVI вв., с. 188-189; A. Mironowicz, Święci w Kościele prawosławnym na Białorusi, [w:] Wilno i kresy północno-wschodnie, t. I., Historia i ludzkie losy, pod red. E. Feliksiak i A. Mironowicza, Białystok 1996,

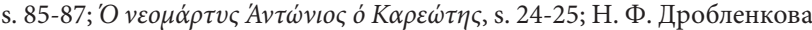
(библиография), Г. М. Прохоров, Киприан, митрополит Киевский и всея Руси, „Словарь книжников и книжности Древней Руси”, вып. 2 (вторая половина XIV - XVI в.). ч. I: A-K / отв. ред. Д. С. Лихачев, Ленинград 1988, с. 465. 


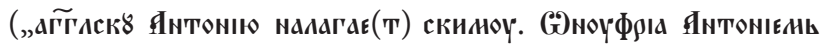

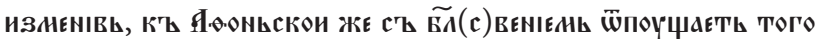
ropt.”, k. 478v.). Mnich Antoni miał towarzyszyć zakonnikom $\mathrm{z}$ Athosu, którzy po pobycie w monasterze supraskim wracali do swych monasterów. Pafnucy nie chciał, ażeby Antoni, z zamiarem poniesienia męczeńskiej śmierci, wyjechał sam. Ihumen był przeciwny zamiarom Antoniego. Nie chciał też, by informacja o wyjeździe Antoniego była powszechnie znana, gdyż wielu mnichów mogło by pójść jego śladem. Zapewne ihumen znał rodzinę zakonnika i nie chciał, żeby cierpiała ona $\mathrm{z}$ powodu jego decyzji. Pafnucy był odpowiedzialny za Antoniego, albowiem to on przyjął go do monasteru i uczynił zakonnikiem. Taka interpretacja tłumaczy ciche postrzyżyny Antoniego w schimę.

W obrzędzie postrzyżyn Antoniego i wysłania go na Athos uczestniczyło niewielu mnichów. Biograf nazywa ich

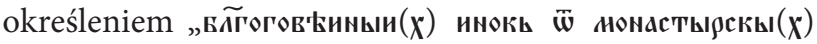
строитель Призвавь штан”, (k. 478v.). Słowo „строитель” w języku słowiańskim ma wiele znaczeń np. ekonom, dozorca, klucznik, opiekun ${ }^{38}$. W tym wypadku termin ten i cała fraza odnosi się do rady starszych mnichów, którzy poufnie uczestniczyli w obrzędzie. W jej skład wchodzili agoryci, którzy założyli monaster i utrzymywali bliskie kontakty z podobnymi ośrodkami na Świętej Górze Athos.

Antoni po otrzymaniu schimy i błogosławieństwa od ihumena Pafnucego udał się na Świętą Górę Athos. Biograf - autor żywotu męczennika - wskazuje, że Athos znajduje się na końcu Europy nad Morzem Egejskim ${ }^{39}$. „,6сть

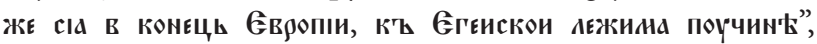
(k. 478v. $)^{40}$. Dla przybyłego z Supraśla mnicha Święta Góra Athos stanowiła ogród Bogurodzicy, miejsce modlitw i pokuty zakonników.

Po przybyciu na Górę Athos mnich Antoni przedstawił mieszkającym tam Ojcom zakonnym swój zamiar oddania życia za Chrystusa. Mnisi athoscy, podobnie jak uprzednio uczynił ihumen Pafnucy, odradzali mu taki rodzaj pokuty. Doświadczeni w życiu zakonnym Ojcowie poradzili schimnikowi, ażeby prowadził życie monastyczne zgodnie ze swym powołaniem w skromności, cierpliwości i pokucie. Według nich sam Bóg wezwie go do męczeństwa i dania świadectwa swej wiary, jeżeli przyjdzie odpowiednia chwila. Następnie Ojcowie poradzili Antoniemu, ażeby zamieszkał w wieży św. Sawy Serbskiego. „Н Ако н\$сть

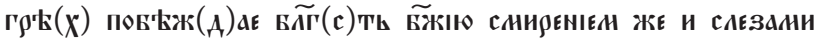

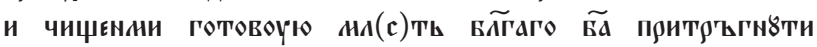

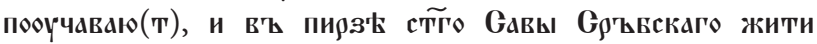
оүстраaю(т) Янтоніа", (k. 478v.).

\footnotetext{
8 И. И. Срезневский, Материаль для словаря древние-русского языка по письменным памятникам, Санкт-Петербург 1903, с. 552-554.

39 Nazwa Europa nie była powszechnie stosowana w tekstach ruskich. Po raz pierwszy spotykamy ją w opowieści o wojnach z Konstantynopolem Nestora Iskandera z XV w. Por. Арх. Леонид (Кавелин), Повесть о Царьграде (его основании и взятии Турками в 1453 году) Нестора Искандера $X V$ века, „Памятники древней письменности и искусства”,

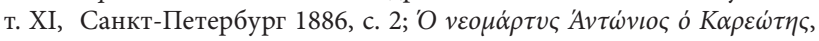
s. 28.

40 W żywocie używa się słowo „поүчинћ”, co w języku słowiańskim oznacza otwarte morze, a nie linię brzegową.
}

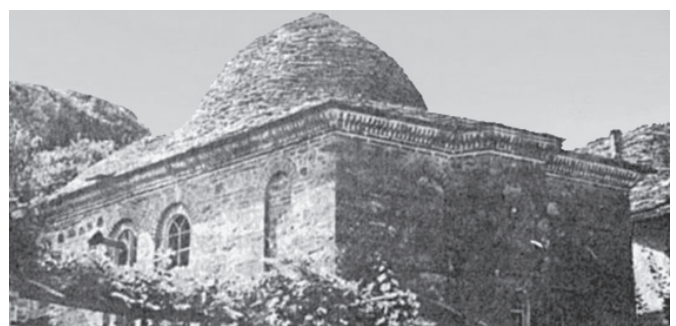

Miejsce po wieży św. Sawy Serbskiego w Karies

(foto $\mathrm{z}$ pocz. XX w.)

Pojawia się problem: gdzie trafił mnich supraski na Świętej Górze Athos? W tym czasie znajdowały się tu trzy wieże św. Sawy Serbskiego. Pierwsza była wzniesiona w starym monasterze ruskim, tam gdzie przebywał św. Sawa podczas swego pierwszego pobytu na Athosie. Druga wieża znajdowała się w monasterze serbskim Chilandar, a trzecia w stolicy athoskiej republiki - Karies $^{41}$. Według A. Turiłowa mnich Antoni trafił do kieliii ${ }^{42}$ w Karies, zwanej „Turıxapıó”, która miała swoją regułę i wieżę ${ }^{43}$. Kielia ta została zbudowana przez św. Sawę, syna króla serbskiego Symeona Neumana (1167-1196), około 1199 r. ${ }^{44}$ Po osiedleniu się św. Sawy w Chilandarze w 1197 r. mnich serbski, dwa lata później, opracował własny typikon, opierając się na regule św. Sawy Jerozolimskiego. Ten typikon obowiązywał w kielii w Karies. Nakładał on surowe zasady życia ascetycznego oparte na poście i modlitwie ${ }^{45}$. Kielia i żyjący w niej mnisi cieszyli się dużym autorytetem w republice athoskiej, zwłaszcza w końcu XV i na początku XVI stulecia. Kielię traktowano jako osobny monaster, a mieszkająca w niej wspólno-

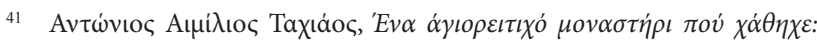

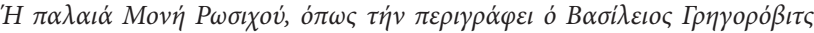

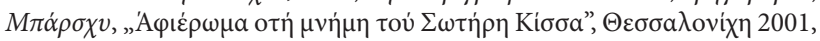
s. 619; С. Ненадовиђ, Осам векова Хиландара. Грађене и грађевине, Београд 1997, с. 21-23; В. Корађ), М. Ковачевиђ, Монастир Хиландар. Конаци и утврђене, Београд 2004, с. 58-62.

42 Kielia, od greckiego słowa cellion, oznacza odizolowany mały budynek z przylegającą kaplicą. Kielia była duchowo, administracyjnie i finansowo zależna od głównego monasteru, pomimo że przebywało w niej nieraz po kilkudziesięciu zakonników.

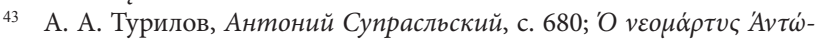

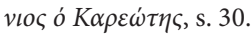

44 Манастир Хиландар, Београд 2000, с. 14-15; Паv. К. Хри́бто, То

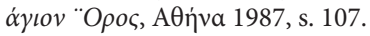

${ }^{45}$ Karejski Typikon jest jednym $\mathrm{z}$ najważniejszych dokumentów w historii religijnej literatury serbskiej. Na 115 wierszach św. Sawa opracował szczegółowe zasady modlitwy, postu i kultu liturgicznego, które miały być realizowane przez kelliote (mnich, który mieszka w kielii) w Karies. Karejski Typikon był wzorowany na starożytnych zasadach i modlitwach ascetów, którzy żyli na pustyniach w Egipcie, Synaju, Palestynie i Syrii. Karejski Typikon wyraził najbardziej podstawowe zrozumienie i przekonania dotyczące istoty ludzkiej. Podczas pobytu św. Sawy w celi w Karies miejsce to było nazywane „słup ortodoksji”. Trwała tu bez przerwy modlitwa oraz powstawały nowe hymny, pieśni i modlitwy ku chwale Boga w Trójcy Świętej. A. E. Tachiaos, Le monachisme serbe de Saint Sava et la tradition hésychaste athonite. „Hilandarski sbornik”, vol. I, Beograd 1966, s. 83-89; М. Живојиновиђ, Светогорске келије и пиргови у средюем веку, Београд 1972, с. 91-102; А. Е. Тахиос, Улога светога Саве у оквиру словенске книжевне делатности на Светој Гори, „Мећународни научни скуп Сава Немањић Свети Сава. Историја и предање. Децембар 1976", Београд 1979, с. 85-89. 
ta posiadała własnego przedstawiciela w zgromadzeniu agioryckim $^{46}$.

Do tego miejsca skierowali Ojcowie athoscy mnicha Antoniego, zalecając mu, by zamknął się w wieży św. Sawy i przestrzegał obowiązującego tam typikonu. Takie życie miało pomóc zakonnikowi supraskiemu w zbawieniu duszy. „И

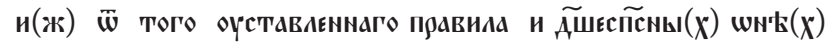

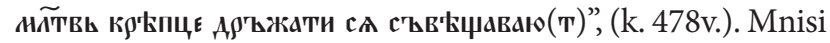
byli przekonani, że przestrzeganie surowej reguły i pozostawanie w ciągłej modlitwie skłoni schimnika Antoniego do odstąpienia od planu męczeństwa za wiarę. Antoni pozostał w wieży św. Sawy i surowo przestrzegał obowiązującej w niej reguły. Według jego hagiografa $\mathrm{z}$ pokorą przyjął taką formę życia i ze łzami oddawał się modlitwie. Jego pobożność była wzorem dla innych przebywających w kielii mnichów. „け)

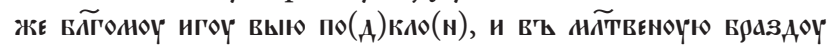

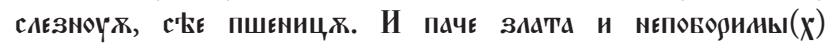

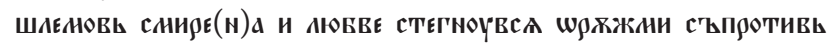

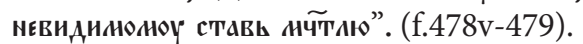

Po kilku latach pobytu Antoniego na Athosie do kielii św. Sawy dotarły informacje o męczeństwie Jana, który pochodził, według biografa świętego, z serbskiego miasteczka w prowincji macedońskiej okupowanej przez Turków.

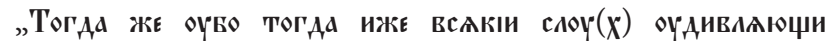

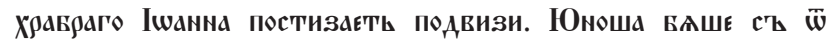
БАГО

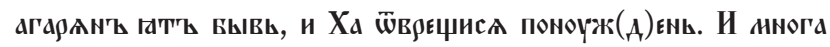

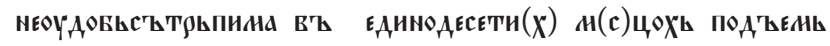

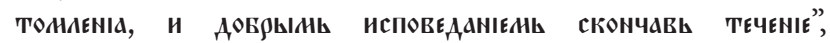
(k. 479). W żywocie św. Antoniego podano, że młodzieniec Jan nie chciał wyrzec się wiary w Chrystusa i za to został doświadczony jedenastomiesięcznym męczeństwem, a potem go zabito.

Wydarzenie to posiada istotne znaczenie w poznaniu biografii męczennika supraskiego. Jeżeli mnich Antoni opuścił Supraśl przed 1510 r., przed śmiercią ihumena Pafnucego, to przybył on na Świętą Górę Athos na początku drugiego dziesięciolecia XVI w. W takiej sytuacji męczeństwo Jana musiało się dokonać po 1510 r. Tymczasem postać męczennika Jana jest bardzo zagadkowa. Według A. Turiłowa św. Jan pochodził on z greckiego miasta Serres. Początkowo badacz ten napisał, że żaden Jan z Serres nie występuje w źródłach hagiograficznych ${ }^{47}$, ale później w innej publikacji wskazał, że święty o takim imieniu i przydomku znany był na Bałkanach ${ }^{48}$. A. Turiłow w 2002 roku odnalazł w rękopisie serbskiego zbornika w Naukowej Biblioteki im. M. Gorkiego w Odessie żywot Jana z Serres, według którego Jan miał ponieść śmierć męczeńską 12

\footnotetext{
46 Ten przywilej opierał się na sfałszowanym liście patriarchy Antoniego z 1392 r. i tomosie cesarza Manuela Paleologa z 1394 r. Oba dokumenty zostały potwierdzone w $1498 \mathrm{r}$. przez patriarchę Joachima i w ten sposób uzyskali swoją ważność. А. Фотиђ, Света Гора и Хиландар у Османском

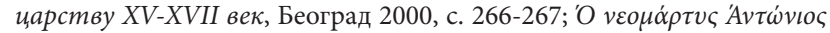
ó $K \alpha \rho \varepsilon \omega \dot{\tau} \eta \varsigma$, s. 31.

47 А. А. Турилов, Антоний Супрасльский, с. 680.

48 О. В. Лосева, Первые новомученики «автоклиты»: греческие и славянские монахи-святогориь , „Афон и славянский мир”. вып. I, Святая Гора 2014, с. 31-32; А. А. Турилов, Иоанн Серрский, „Православная энциклопедия”, т. XXIV, Москва 2010, с. 608.
}

maja $1507 \mathrm{roku}^{49}$. Na tej podstawie Turiłow wysunął teorię, że święty Antoni przybył na św. Górę Athos przed 1507 r. a jego śmierć nastąpiła 17 lutego $1508 \mathrm{r}$. Na pierwszy rzut oka pogląd ten może wydawać się za wiarygodny: mnich Onufry mógł być podstrzyżony jeszcze w Gródku na początku XVI wieku, jako schimnik Antoni wraz z innymi zakonnikami athoskimi udać się na Athos przed 1507 r. i rzeczywiście ponieść śmierć w 1508 r. na wieść o męczeństwie młodzieńca Jana pochodzącego z serbskiego miasta w Macedonii. Za tym miałaby też świadczyć jego głębokie pragnienie oddania życia za wiarę.

Nie rozstrzygając ostatecznie o dacie męczeństwa św. Antoniego Supraskiego nie wydaje mi się, że taka chronologia wydarzeń miała miejsce. Anatol Turiłow nie wziął pod uwagę faktu, że monaster supraski na nowym miejscu zaczął funkcjonować dopiero od 1507 r. a mnich Onufry wstąpił do niego, kiedy był w budowie. $\mathrm{Z}$ tego powodu opuszczenie monasteru supraskiego przez schimnika Antoniego, jego podróż do św. Góry Athos, pobyt w celi św. Sawy Serbskiego musiała mu zając co najmniej dwa lub trzy lata. Odnalezienie przez A. Turiłowa nowego żywotu Jana z Serres ma ważne znaczenie, ale nie zmienia to faktu że Antoni Supraski podjął swoją decyzję o męczeństwie na wieść o śmierci innej postaci po $1510 \mathrm{r}$.

Z początku XVI wieku znane były, oprócz Jana z Serres, imiona kilku innych męczenników zamordowanych przez Turków: Malachiasza (1500), Jerzego z Serbii (11 lutego 1515 r.), mnicha Jakuba z Kastorii z jego uczniami, diakona Jakuba i mnicha Dionizego (1519) ${ }^{50}$.

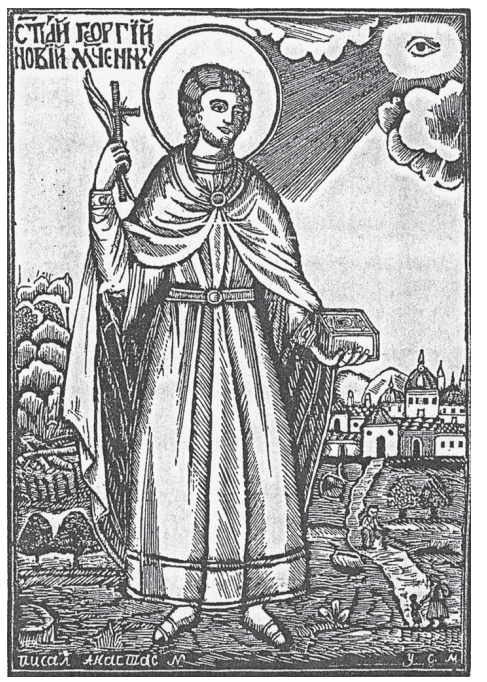

Św. Jerzy z Kratowa

O męczeństwie którego z nich dowiedział się Antoni? Odrzucając ze względów chronologicznych Malachiasza, możemy brać pod uwagę jedynie męczennika Jerzego i mnicha Jakuba $z$ Kastorii. Ten ostatni jednak nie był Ser-

\footnotetext{
49 А. А. Турилов, Житие преподобномученика Антония Супрасльского и славянские жития балканских новомучеников XVI в. (к постановке проблемь), „Hagiographia Slavica”, ed. Herausg. von J. Reinhart, Munchen-Berlin-Wien 2013, („Wiener Slawistischer Almanach. Sonderband". Bd. 82), s. 269-270

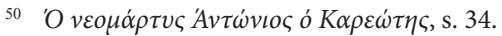


bem, a w dodatku Jakub z Kastorii był mnichem, o czym z pewnością napisałby biograf św. Antoniego. W tej sytuacji pozostaje jedynie osoba Jerzego $\mathrm{z}$ Kratowa ${ }^{51}$, miasta macedońskiego uznawanego wówczas za serbskie. Kratowo było położone na wschód od Skopie i znane z bogatych kopalń. Św. Jerzy był obdarzony powszechnym kultem wśród mieszkańców tej prowincji, pomimo że poniósł on śmierć męczeńską w Sofiii ${ }^{52}$.

W żywocie św. Antoniego znajdujemy wiele nieścisłości odnośnie męczeństwa św. Jerzego. Jego autor pomylił imię serbskiego męczennika, zamieniając imię Jana z Serres z Jerzym z Kratowa, którego śmierć miała przypaść na 11 lutego 1515 roku. O jedenastomiesięcznym męczeństwie młodzieńca Jerzego nie znajdujemy potwierdzenia $\mathrm{w}$ jego biografii. Analizując uważnie życie św. Jerzego, od schwytania przez Turków do śmierci, możemy założyć, że jego męczeństwo trwało $11 \mathrm{dni}$, a nie miesięcy. Prawdziwe są informacje odnośnie rodziców św. Jerzego: Dymitra i Sary, ale nie znajdujemy informacji odnośnie ich stanu społecznego i zawodu. Sara i Dymitr z Kratowa nie byli złotnikami. Według A. Tachiaosa autor życiorysu św. Antoniego pomylił ten fragment żywotu św. Jerzego $z$ danymi odnoszącymi się do zakonnika supraskiego. Według niego informacje dotyczące dobrego wykształcenia męczennika w młodości i bogatych rodziców, którzy pragnęli uczyć go sztuki złotniczej, dotyczą nie tyle Jerzego co Antoniego ${ }^{53}$. Ten pogląd greckiego badacza nie znajduje uzasadnienia, albowiem w żywocie św. Jerzego wyraźnie wspomina się, że rodzice wysłali go do Sofii, „aby poznał kunszt złotniczy i biegle wyuczył się rzemiosła" ${ }^{\text {. }}$. Ta informacja nie uzupełnia nam wiedzy o pochodzeniu św. Antoniego, który, jak się wydaje, pochodził z bogatej mieszczańskiej rodziny, ale nie ma żadnych danych, ażeby potwierdzić przynależność rodziców do cechu złotników ${ }^{55}$.

Historia męczeństwa św. Jerzego włączona została do żywotu św. Antoniego Supraskiego. Autor pierwszej wersji żywota mógł popełnić wiele błędów, mylących fakty męczenników z początków XVI w. Wynikały one albo z błędnego odczytania starszego pierwowzoru, albo z niedokładnego poznania przekazu ustnego. Bardziej prawdopodobna wydaje się druga teza, mówiąca o tym, że autor żywotu św. Antoniego oparł się na słownym opowiadaniu o św. Je-

\footnotetext{
51 П. Дикенов, Софийски книжовники праз XVI век, София 1939, с. 58-74; Д. Богдановић, Житије Георгиј Кратовца, „Зборник историје књижевности”, књ. 10, (1976), с. 203-267; Мбчение на Георги Нови Софийски om Поп Пейо, „Старабългарска литература”, т. IV. Ред. Кл. Иванова, София 1986, с. 291-308, 608-611; N. M. Vaporis, Witnesess for Christ. Orthodox Christian Neomartyrs of the Ottoman Period 1437-1860, Crestwood, New York 2000, s. 45-57.

52 Историја српского народа. Друга књига. Доба борби за очуване и обнову државе, Београд 1982, с. 23, 105, 498-499; А. А. Турилов, Хр. Темелски, Георгий Новый Кратовский, „Православная энциклопедия" т. ХІ, Москва 2006.

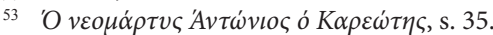

54 Żywot świętego Georgiego Nowego, [w:] Siedem niebios i ziemia. Antologia dawnej prozy bułgarskiej. Wybór, przekład i wstęp T. Dąbek-Wirgowa, Warszawa 1983, s. 226

55 Cech taki był w Bielsku na Podlasiu. A. Jabłonowski, Podlasie, t. VI, cz. III, Polska XVI wieku, „Źródła dziejowe”, t. XVII, cz. 3, Warszawa 1910, s. 174 .
}

rzym, a nie na spisanym źródle. Jeżeli uznamy, że autorem żywota był pochodzący z monasteru supraskiego Arseniusz to przeplatanie faktów z biografii obu męczenników można uznać za w pełni realną. Męczeństwo św. Jerzego przyćmiło wcześniejsze męczeństwo Jana z Serres i może dlatego było $\mathrm{w}$ drugiej połowie lat trzydziestych XVI wieku bardziej znane wśród mnichów athoskich. Księga o męczeństwie św. Jerzego została napisana przez ks. Peio (Пейо) między 1516 a 1539 r. $^{56}$

Męczeństwo młodzieńca Jerzego musiało się dokonać podczas pobytu mnicha Antoniego w wieży św. Sawy. Informacja o tym dotarła do kielii poprzez pielgrzymów albo mnichów serbskich lub bułgarskich. Mnich Antoni słysząc o męczeńskiej śmierci młodzieńca Jerzego, zamęczonego przez Turków, podjął decyzję pójścia jego śladami. Przekaz o Jerzym zakonnik supraski uznał za dany mu znak Boży, ażeby mógł wykonać swój pierwotny zamysł - umrzeć za wiarę chrześcijańską. W tym celu mnich pozostawił kielię, opuścił Świętą Górę Athos i udał się do Salonik, do jed-

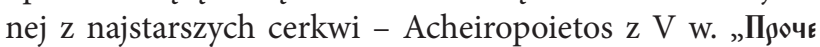

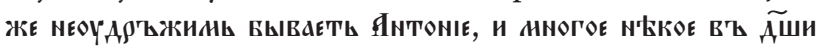

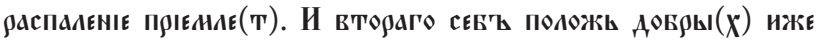

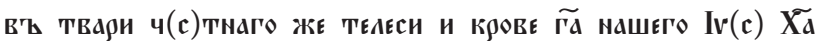

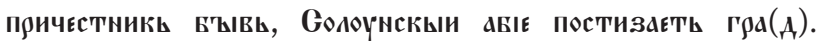

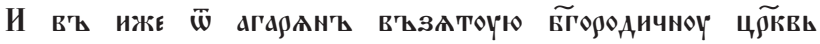

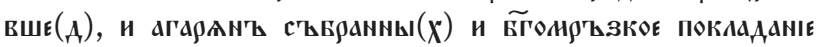

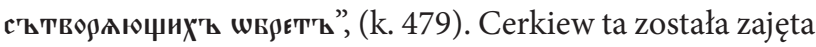
przez Turków i w 1430 r. przerobiona przez sułtana Murata II (1421-1451) na meczet. Murat II polecił na jednej z kolumn cerkiewnych wyrzeźbić napis upamiętniający zdobycie przez niego miasta ${ }^{57}$.

Po przybyciu do Salonik schimnik Antoni wszedł do cerkwi Bogurodzicy Acheiropoietos w czasie, kiedy Turcy sprawowali muzułmańskie obrzędy. Prawdopodobnie był to piątek, albowiem w tym dniu muzułmanie zbierali się na nabożeństwa. W czasie muzułmańskiego nabożeństwa Antoni Supraski zaczął się modlić, wykonał znak krzyża

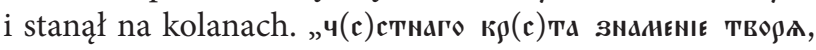

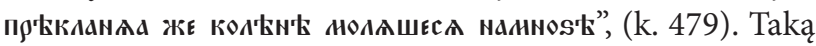
postawę mnicha muzułmanie uznali za obrazę ich religii, schwytali Antoniego i poddali torturom. Zakonnik został zamknięty $\mathrm{w}$ więzieniu, pozbawiony pożywienia i picia.

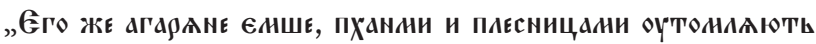

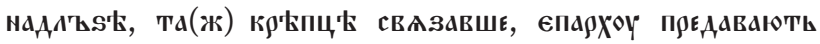

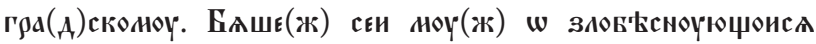

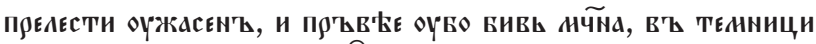

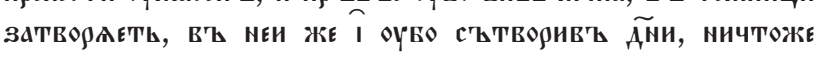
въькоүснв'ъ", (k. 479).

Biograf świętego męczennika używa greckiego terminu „єпарX ${ }^{1 ”}$, co oznacza według terminologii bizantyjskiej

\footnotetext{
56 П. Дикенов, Софийски книжовники праз XVI век, с. 81-83; Siedem niebios i ziemia, s. 226.

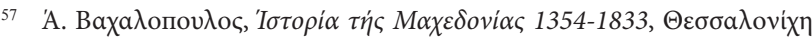

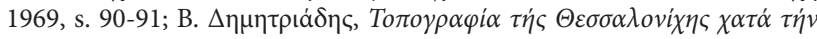

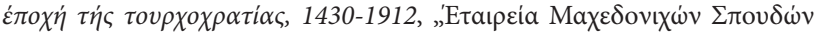

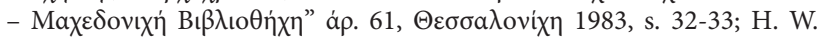
Lowry, Portrait of a City: The Population and Topography of Ottoman Selanik (Thessaloniki) in the Year 1478, $\Delta i \pi \tau u x \alpha$, B. 'Atrivai 1980-1981,

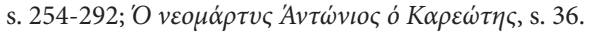


namiestnika prowincji. Termin ten był znany wśród Słowian w tekstach greckich ${ }^{58}$. Określano nim również sędziego. W tym konkretnym przypadku, według A. Tachiaosa, mowa jest o paszy - zarządcy miasta. Według żywotu świętego to pasza polecił zamknąć Antoniego w więzieniu i pozostawić go bez jedzenia przez dziesięć dni. Później kazał przyprowadzić mnicha przed oblicze sądu, by tam wyrzekł się on wiary chrześcijańskiej. Turcy uważali, że Antoni porzuci prawosławie, jak to uczyniło wielu ówczesnych mieszkańców Salonik. Osoby te, przyjmując islam, pragnęły ratować swe życie lub utrzymać swoją dotychczasową pozycję społeczną ${ }^{59}$. Tymczasem na przesłuchaniu mnich supraski odmówił przejścia na islam, potwierdził swą wiarę w jedynego Boga i w ostrej formie potępił prześladowanie chrześcijan. Według żywota nazwał paszę „brudnym psem” i „dziedzicem wiecznego ognia”. „Покиває(ж) м(ч)мкь

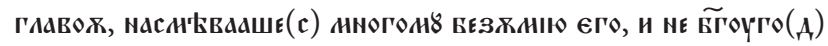

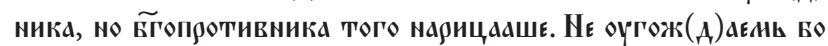

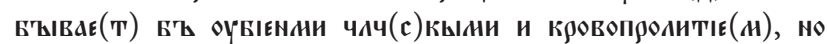

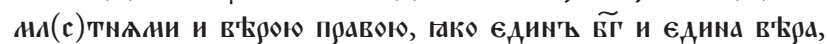

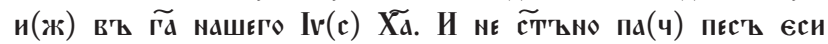
гнилыи и насл'(А)ни(к) шгнА в'Ечнаго", (k. 479v.) Antoni, jako Rusin, nie znał języka tureckiego i z pewnością jego rozmowa z paszą i sędzią odbywała się w obecności tłumacza.

Pasza domagał się od sędziego, aby ten skazał Antoniego na śmierć poprzez spalenie. Ten jednak nie wydał wyroku i odesłał mnicha do wyższego sędziego. W tym czasie w Imperium Osmańskim niższy sędzia „kadis asker”, gdy miał wątpliwości w sprawie wyroku, odsyłał podsądnego do wyższego sędziego „kadisa”"60. Kadis ponownie chciał zmusić Antoniego do wyrzeczenia się wiary chrześcijańskiej. Ten nie tylko tego nie uczynil, ale swymi gestami pokazał paszy i sędziemu, że pójdą do wiecznego ognia. W reakcji na gesty supraskiego zakonnika sędzia polecił spalić ciało mnicha, a popiół rozrzucić w powietrzu. W ten sposób Turcy chcieli uniknąć sytuacji, w której ciało Antoniego mogło się stać obiektem kultu wśród chrześcijan ${ }^{61}$. „И

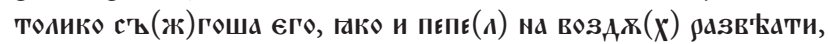

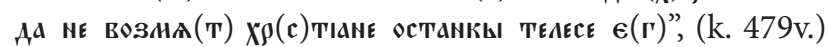
Kara spalenia była powszechnie stosowana wobec chrześcijańskich męczenników tej epoki.

Dokładną datę męczeństwa św. Antoniego można ustalić na podstawie danych pośrednich. Według wiarygodnego żywotu św. Jerzego z Kratowa można przyjąć, że śmierć Antoniego, mnicha supraskiego, nastąpiła po 1 (11)

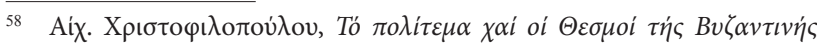

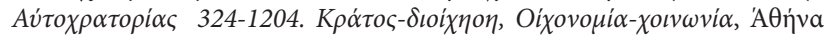

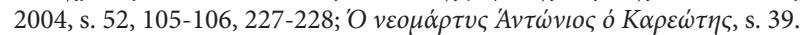

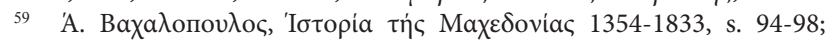

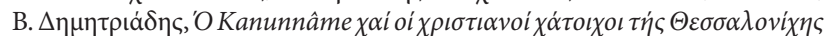

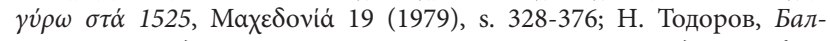
канският град XV-XIX век. Соцално-икономическо и демограбско развитие, София 1972, с. 42-49.

${ }_{60}$ H. Inalcik, The Rise of the Ottoman Empire, [in:] A. History of the Ottoman Empire to 1730, ed. M. A. Cook, Cambridge University Press 1976, s. 46-47; Н. Тодоров, Балканският град XV-XIX век. Соиалноикономическо и демографско развитие, с. 101-102.

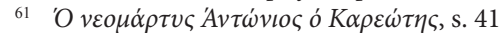

lutym 1515 r. Zanim dotarła do Karies wieść o męczeństwie młodzieńca serbskiego minęło wiele miesięcy. Logiczne jest więc wyznaczenie daty śmierci Antoniego według kalendarze juliańskiego na dzień 4 (14) lutego 1516 r. Ta data dzienna została wstawiona do wierszowanego Protogu. Zapewne autor żywotu świętego wiedział, kiedy nastąpiło męczeństwo mnicha. Tę datę dzienną czcili mnisi suprascy, wpisując św. Antoniego do wykazu świętych na miesiąc luty. Dzień 4 lutego z 1516 r. według kalendarza juliańskiego obecnie odpowiada dacie 17 lutego według kalendarza gregoriańskiego. Z tego powodu dzień 17 luty został przyjęty jako dzień pamięci św. Antoniego w Cerkwi prawosławnej.

\section{Tekst żywotu św. Antoniego Supraskiego}

$\mathrm{w}$ wersji oryginalnej spisany w latach $1540-1541^{62}$.

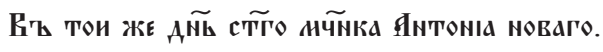
Оти (X).

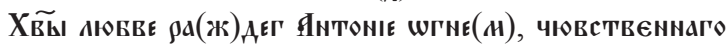

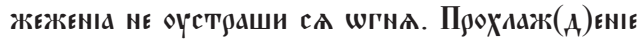

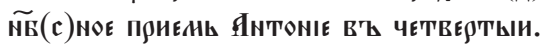

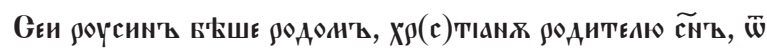

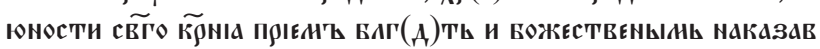
сА Пис

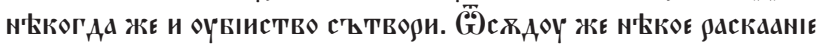

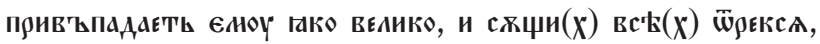

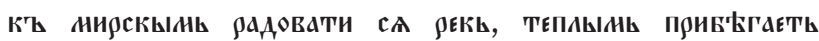

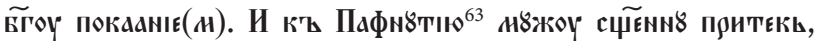

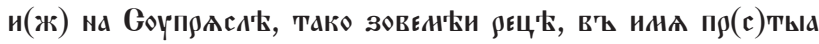

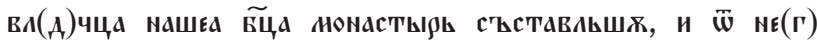

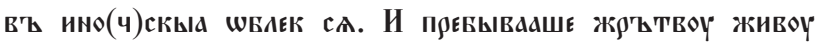

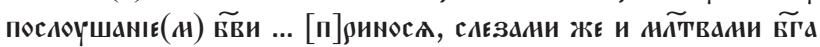

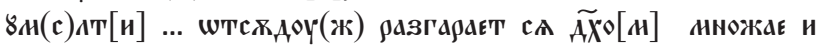

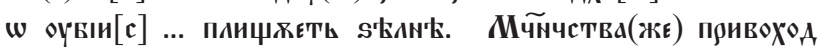

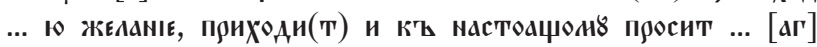

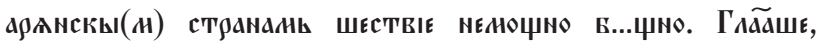

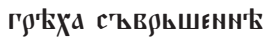

\section{(f. $478 \mathrm{v}$.)}

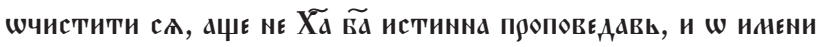

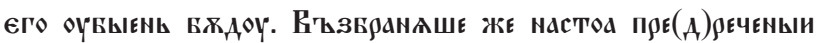

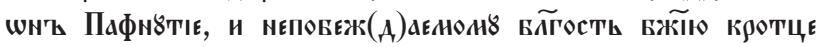

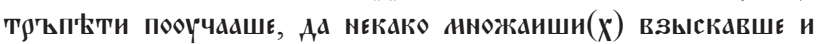

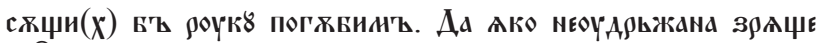

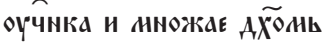

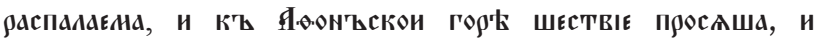

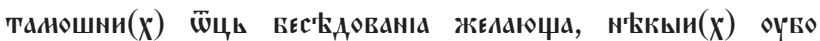

\footnotetext{
${ }^{62}$ Prologion Wierszowy, Państwowe Muzeum Historyczne w Moskwie, kol. A. S. Uvarova № 56-1, k. 478-479v.

63 Na marginesie XVI - wieczny dopisek „игочмен си Gочпрако”.
} 


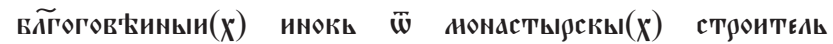

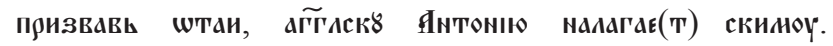

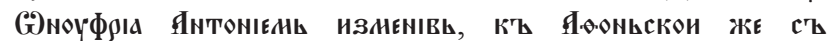

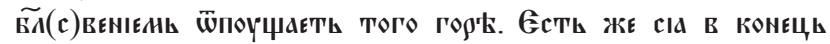

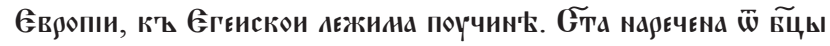

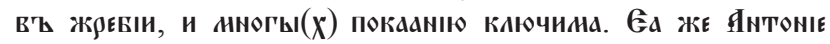

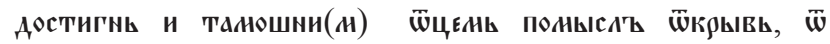

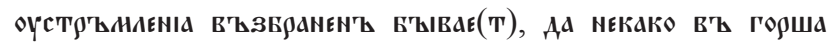

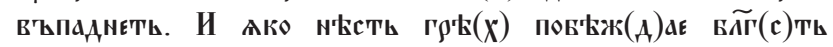
БЖЕІЮ САНОЕНІЕН ЖЕ И САЕЗАНИ И ЧНЧЕНАИ ГОТОВОНЮ НА(c)

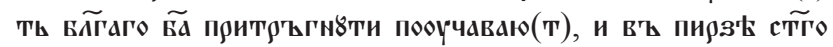

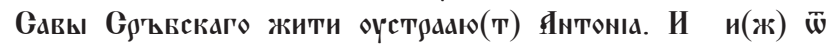

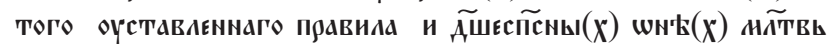

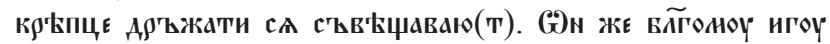

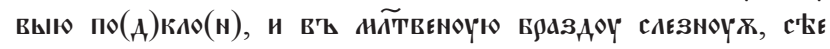
ПшємицХ

(f.479).

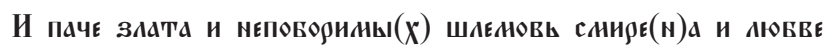

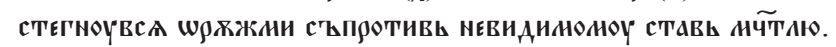

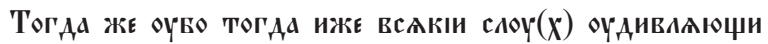

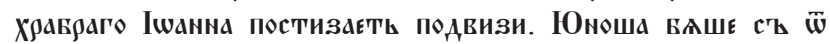

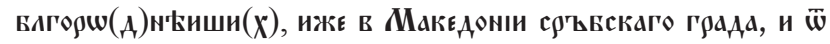

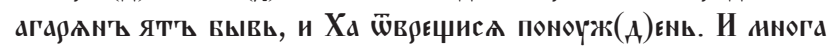

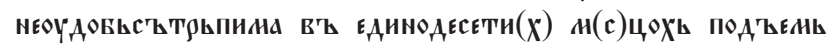
TOAHENIA, И АОБОЫНК ИСПОВЕАДНIЕНЬ СКОНЧАВЬ ТЕЧЕНIE.

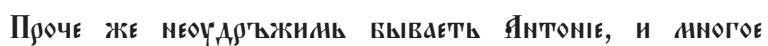

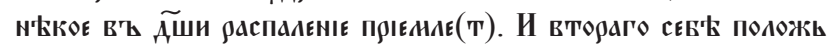

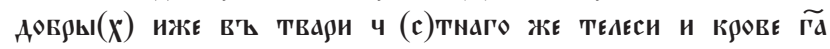
нашего $\operatorname{Iv}(\mathfrak{c})$ Ха Причестникь БЪІвь, Gолоүнскыи аБІе

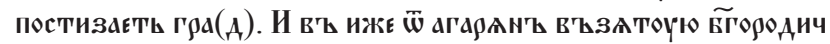

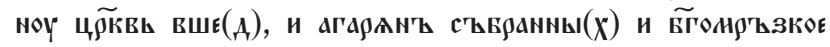

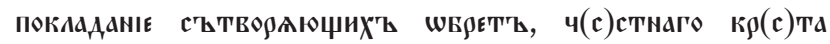

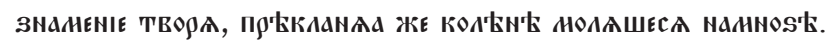
GГО ЖЕ वГАЯАНЕ ЄНШЕ, ПХАННИ И ПАЕСНИЦАНИ ОУТОНААЮТЬ

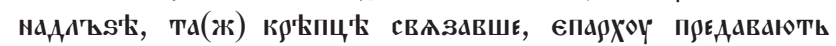

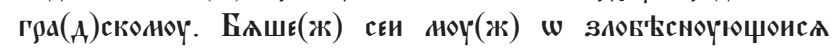

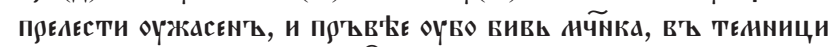

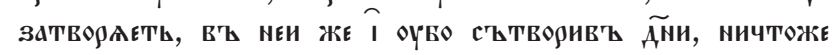

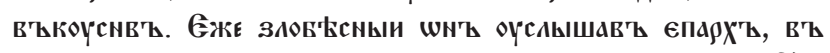

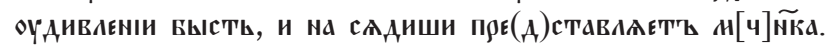
Gaовесы

\section{(f. $479 v)$}

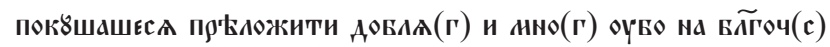

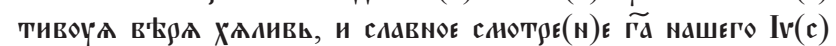
Ха ПотечЗавь. Мченкь Же Пакы сапротивн' Ха ба истина,

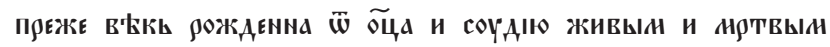

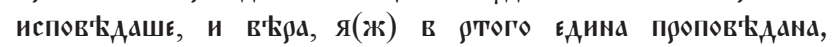
того(ж) б̈врьГшаса оГнь Шжидаєть неУГасидын. ХвалАше

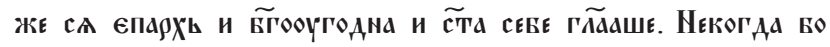

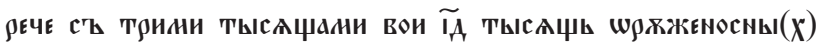
Пови $(X)$. Покиває(ж) н(Ч)нкь ГАавож, насн中вадше(c)

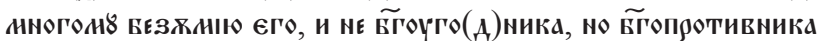

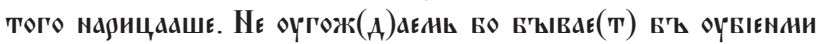

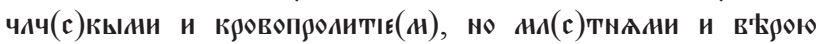

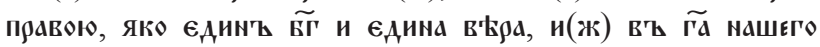

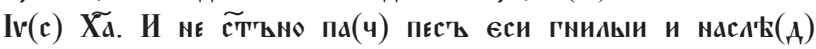

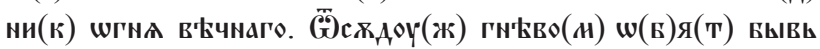

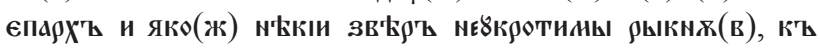

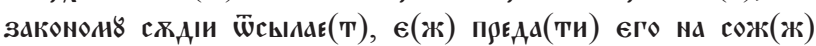

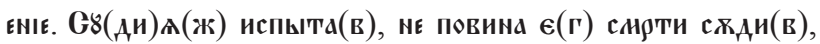

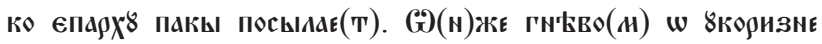

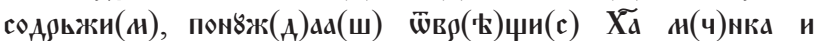

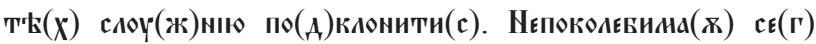

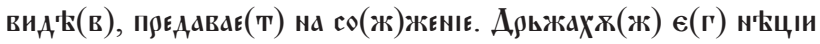

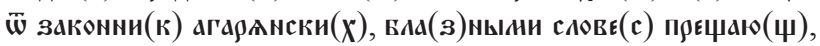

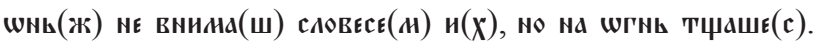
Та(ж) сли(н) исполни(в) оүста и въ шб аа(з) Арьжаџа(г) и

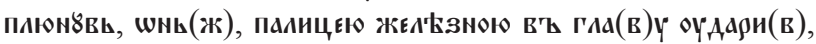

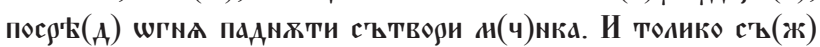

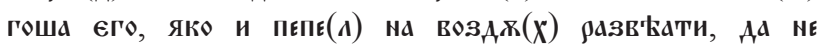

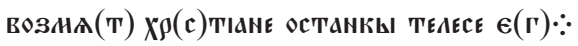

Karty, na których został spisany żywot św. Antoniego Supraskiego (k. 478-479v) uległy częściowemu zniszczeniu. W wydaniu żywotu luki znajdujące się w tekście zostały zaznaczone ciągłymi kropkami. W słowiańskim pierwowzorze opuszczone litery są zaznaczone w kwadratowych nawiasach, a dopiski nad tekstem są umieszczone w nawiasach zwykłych.

\section{Тропарь прп. Антонию Супрасльскому}

Глас 1, подобен: Пустынный житель

$\mathrm{B}$ обители Супрасльстей яко солнце воссиял еси, и горы Афонския покаяния ради достигл еси, жестокая мучения претерпел си, Антоние отче наш, сего ради изливаеши благодать, всем с верою взывающим: слава давшему ти крепость, слава венчавшему тя, слава подающему тобою, грехов оставление.

\section{Кондак прп. Антонию Супрасльскому}

\section{Глас 3, подобен}

Д ева днесь Страстотерпца добляго, покаяния образ, восхвалим вернии, Антония преподобного, той бо есть заступник изрядный и благодатный, всем святым на небесех сожитель дивный, изливающий присно неоскудныя щедроты, к нему притекающим.

Tropar i kondak ku czci św. Antoniego Supraskiego opracował Marcin Abijski 


\section{Bibliografia}

\section{Źródła rękopiśmienne}

Archiwum Państwowe w Krakowie, Archiwum Młynowskie Chodkiewiczów, sygn. 36, nr 29.

Biblioteka Litewskiej Akademii Nauk w Wilnie, Oddział Rękopisów, f. 19 , nr 100.

Biblioteka Naukowa Uniwersytetu Wileńskiego, Oddział Rękopisów, F 58-7, B 1993.

Państwowym Muzeum Historycznym w Moskwie, kol. A. S. Uvarova № 56-1.

\section{Źródła drukowane}

Археографический сборник документов, относящихся кистории Северо-Западной Руси, издаваемый при управлении Виленского учебного округа, т. IX, Вильна, 1870.

Добрянский Ф. Н., Описание рукописей Виленской публичной библиотеки, иерковнославянских и русских, Вильна 1882.

Документы относящиеся к истории православия в Западной $P y c u$, „Вестник Юго-Западной и Западной России”, г. V, 1867 , кн. 1, т. I, отд. 1.

Jabłonowski A., Podlasie, t. VI, cz. III, Polska XVI wieku, „Źródła dziejowe", t. XVII, cz. 3, Warszawa 1910.

Мъчение на Георги Нови Софийски от Поп Пейо, „Старабългарска литература”, т. IV. Ред. Кл. Иванова, София 1986.

Описание Рукописного отделения Библиотеки Императорской академии наук. I. Рукописи, т. I: (I. Книги священного писания и II. Книги богослужебныя) / сост. В. И. Сперанский и Ф. И. Покровский, Санкт-Петербург 1904.

Rękopisy supraskie w zbiorach krajowych i obcych, opr. A. Mironowicz, Białystok 2014.

Славянские рукописи Афоних обителей (сост. А. А. Турилов и Л. В. Мошкова), под ред. А. Э. Н. Тахиоса, Фессалоники 1999.

Супрасълски или Ретков сборник, Й. Заимов, увод и коментар на старобългарски текст, М. Капалдо, подбор и коментар на гръцкия текст, т. I, София 1982, т. II, София 1983.

Summariusz dokumentów do dóbr supraskich, opr. A. Mironowicz, Białystok 2009.

Żywot świętego Georgiego Nowego, [w:] Siedem niebios i ziemia. Antologia dawnej prozy bułgarskiej. Wybór, przekład i wstęp T. Dąbek-Wirgowa, Warszawa 1983.

\section{Literatura}

Арх. Леонид (Кавелин), Повесть о Царьграде (его основании и взятии Турками в 1453 году) Нестора Искандера XV века, „Памятники древней письменности и искусства”, т. XI, Санкт-Петербург 1886.

Арх. Леонид (Кавелин), Системаматическое описание в 4 частях, с 13 снимками славяно-русских рукописей собрания граба А. С. Уварова, ч. II, Москва 1893.

Бантыш-Каменский Н. Н., Реестры греческим делам Московского архива Коллегии иностранных дел, Москва 2001.

Baronas D., Trys Vilniaus Kankiniai. Gyvenimas ir Istorija, Vilnius 2000.

Баронас Д., По поводу литературной истории Мучения трех виленских мучеников, "Krakowsko-Wileńskie Studia Slawi- styczne”, t. III, pod red. W. Stępniak-Minczewej, A. Naumowa, Kraków 2001.

Белецкий А., Митрополитъ Іосифг ІІ Солтанъ и отношение его къ Супрасльскому монастьрю, Вильна 1899.

Бельчиков Н. Ф., Бегунов Ю. К., Рождественский Н. П., Справочник-указатель печатных описаний славяно-русских рукописей, Москва 1963.

Богданович Д., Каталог кирилских рукописа манастира Хиландара, Београд 1978.

Богдановић Д., Житије Георгиј Кратови,, „Зборник историје књижевности”, књ. 10, (1976).

Буднов Н. Д., „Славянские Прологи”, Методологическое пособие по описании славянию-русских рукописей для Сводного каталога рукописей, хранящихся в СССР, выпуск I, Москва 1973.

Charkiewicz J., Św. Antoni Supraski, „Wiadomości Polskiego Autokefalicznego Kościoła Prawosławnego", nr 3(184), 2005.

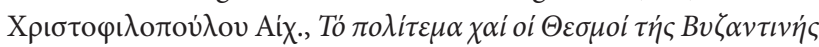

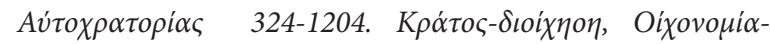

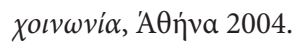

Cicennienè R., Lietuvoc Didžiosos Kunigaištytès rankraštystės knygos kultūra (iki XVI a antroposios pusès): daktaro disertacija, Vilnius 2011.

Дикенов П., Софийски книжовники праз XVI век, София 1939.

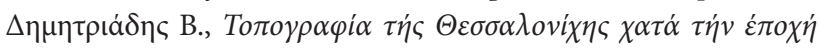

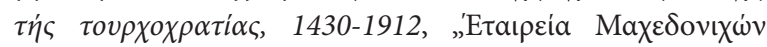

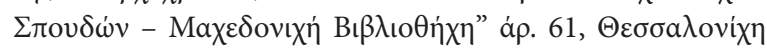
1983.

Дробленкова Н. Ф. (библиография), Прохоров Г. М. , Киприан, митрополит Киевский и всея Руси, „Словарь книжников и книжности Древней Руси”, вып. 2 (вторая половина XIV - XVI в.). ч. I: А-К / отв. ред. Д. С. Лихачев, Ленинград 1988.

Флоря Б. Н., Шлевис Г., Зеленина Я. Э., Антоний, Иоанн и Евстафий, „Православная энциклопедия”, т. XI, Москва 2001.

Фотиђ А., Света Гора и Хиландар у Османском иарству XV -XVII век, Београд 2000.

Григорович-Барский В. И., Очерк путешествия по Европейской Туриии, Казань 1848;

Григорович-Барский В. И., Первое посещение Св. Абонской горы, Санкт-Петербург 1884;

Григорович-Барский В. И., Второе посещение Святой горы, Санкт-Петербург 1887;

Григорович-Барский В. И., Три древних сказания о Св. горе Абонской и краткое описание Св. Горы, Москва 1895;

Грушевський М., Історія України Руси, т. VI, Київ-Львів 1907. Inalcik H., The Rise of the Ottoman Empire, [in:] A. History of the Ottoman Empire to 1730, ed. M. A. Cook, Cambridge University Press 1976.

Историја српского народа. Друга књига. Доба борби за очуване и обнову државе, Београд 1982.

Kaszlej A., Dzieje kodeksu supraskiego, Supraśl 1997.

Kierejczuk E., Kodeks supraski wśród zbiorów biblioteki monasteru supraskiego. Kilka hipotez w sprawie czasu przybycia Minieji 
Czetnej z XI wieku do Supraśla, „Latopisy Akademii Supraskiej”, pod red. U. Pawluczuk, vol. II, Białystok 2011.

Корађ В., Ковачевиђ М., Монастир Хиландар. Конаци и утврђене, Београд 2004.

Кочетов Д. Б., Кузьмин А. В., Шлевис Г. П., Виленский во имя Святой Тройцы мужсой монастырь, „Православная энцыклопедия", т. VIII, Москва 2004.

Krustev G., Boyadjiev A., On the Dating of Codex Suprasliensis, [w:] Rediscovery. Bulgarian Codex Supraslienis of 10th centu$r y$, ed. A. Miltenova, Sofia 2012.

Лабынцев Ю. А., Православная Академия Ходкевичей и ее издания, Минск 1996.

Laucevičius E., XV - XVIII a. knygu įrišimai Lietuvos bibliotekose, Vilnius 1976.

Лосева О. В., Первые новомученики «автоклить»: греческие и славянские монахи-святогорцы, „Афон и славянский мир”. вып. І, Святая Гора 2014.

Lowry H. W., Portrait of a City: The Population and Topography of Ottoman Selanik (Thessaloniki) in the Year 1478, $\Delta \mathbf{i} \pi \tau \chi \chi \alpha$, B. 'Atrivaí 1980-1981.

Lulewicz H., Sołtan Aleksandrowicz, „Polski Słownik Biograficzny", t. XL, Warszawa-Kraków 2001.

Meyendorff J., The Three Lithuanian Martyrs: Byzantium and Lithuania in the Fourteenth Century, „Eikon und Logos. Beiträge zur Erforschung byzantinischer Kulturtraditionen”, Band 2, Halle 1981.

Miklosich Fr. et Müller Ios., Acta Patriarchatus Constantinopolitani, vol. I, Vindobonae 1860.

Митрополит Макарий, История Русской Церкви, кн. V, Москва 1996.

Mironowicz A., Biblioteka monasteru supraskiego w XVI wieku, „Białoruskie Zeszyty Historyczne”, nr 36, Białystok 2011.

Миронович А., Библиотека Супрасльского монастыря в XVI веке, [w:] Rediscovery. Bulgarian Codex Supraslienis of 10th century, ed. A. Miltenova, Sofia 2012.

Mironowicz A., Ewangelizacja "prosta mowa” w XVI wieku, „Latopisy Akademii Supraskiej”, vol. III, pod red. U. Pawluczuk, Białystok 2012.

Mironowicz A., Kodeks supraski, „Białostocczyzna” 1988, nr 1(9).

Mironowicz A., Kościół prawosławny w państwie Piastów i Jagiellonów, Białystok 2003

Mironowicz A., Literatura bizantyjska w Kościele prawosławnym na terenie Wielkiego Księstwa Litewskiego w XVI wie$k u$, „Търновска Книжовна Школа”, Търново и идеята за Християнския Универсализъм XII-XV век, т. IX, Велико Търново 2011.

Mironowicz A., O początkach monasteru supraskiego i jego fundatorach, Supraśl 2013.

Mironowicz A., Podlaskie ośrodki i organizacje prawosławne w XVI i XVII wieku, Białystok 1991.

Mironowicz A., Sobory wileńskie 1509 i 1514 roku, („Synody Cerkwi Prawosławnej w I Rzeczypospolitej”). „Latopisy Akademii Supraskiej”, vol. V, pod red. M. Kuczyńskiej i U. Pawluczuk, Białystok 2014.

Mironowicz A., Supraśl jako ośrodek kulturalno-religijny w XVI wieku, Leiman 1984.

Mironowicz A., Święci w Kościele prawosławnym na Białorusi, [w:] Wilno i kresy pótnocno-wschodnie, t. I., Historia i ludz- kie losy, pod red. E. Feliksiak i A. Mironowicza, Białystok 1996.

Mironowicz A., Tożsamość i tolerancja w rozumieniu prawosławnych zakonników supraskich w XVI wieku, „Rocznik Teologiczny", R. XL, z. 1-2, Warszawa 1998.

Mironowicz A., Związki literackie Kijowa z monasterem supraskim w XVI wieku, „Slavia Orientalis”, t. XXXVIII, nr 3-4, 1989.

Mironowicz A., Związki monasteru supraskiego ze Świętą Góra Athos w XVI wieku, [w:] Święta Góra Athos w kulturze Europy. Europa w kulturze Athos, pod red. M. Kuczyńskiej, Gniezno 2009.

Mironowicz A., Życie monastyczne na Podlasiu, Białystok 1998; Oddziaływanie kultury ruskiej na życie duchowe zakonników monasteru supraskiego w XVI wieku, [w:] Oblicza wschodu w kulturze polskiej, pod. red. G. Kotlarskiego i M. Figury, Poznań 1999.

Mironowicz Antoni i Marcin, Św. Antoni Supraski, Białystok 2014.

Морозова Н. А., Темчин С. Ю., Древнейшие рукописи Супрасльского Благовещенского монастыря (1500-1532 г2.) [w:] Z dziejów monasteru supraskiego, Supraśl-Białystok 2005.

Модест (Стрельбицкий), Супрасльский Благовещенский монастырь, «Вестник Западной России», т. I, кн. 2, Вильно 1867.

Ненадовиђ С., Осам векова Хиландара. Грађене и грађевине, Београд 1997.

Николай (Далматов), Супрасльский Благовещенский монастырь, Санкт-Петербург 1892.

Осам векова Хиландара: историја, духовни живот, кжижевност, уметност и архитектура, Београд 2000.

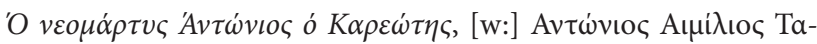

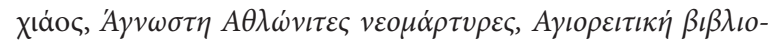
$\theta \dot{\eta} \kappa \eta$, 'Aүıо 'О

Петков Г., Стишнят Пролог в старата бъларска, сръбска и руска литература XIV-XV в., „Археография, текстология и издание на проложни стихове”, Пловдив 2000.

Петр (Пиголь), игум., Преп. Григорий Синаит и его духовные преемники, Москва 1999.

Podskalsky G., Griechische Theologie In der Zeit der Türkenherrschaft (1453-1821): die Orthodoxie im Spannunsgsfeld der nachreformatischen Konfessionen des Westens, München 1988.

Покровский Ф., Археологическая карта Гроденской губерни, Вильна 1895.

Рогов А. И., Литературные связи Белоруссии с балканскими странами в XV-XVI вв., [в:] Славянские титературы. VIII Международный съезд славистов, Загреб-Любляна, сентябрь 1978 г. Доклады советской делегации, Москва 1978.

Рогов А. И., Супрасль как один из изентров культурных связей Белоруссии с другими славянскими странами, [в:] Славяне в эпоху феодализма, Москва 1978.

Самодурова Ю. С., Редакиионная принадлежность бельского Стишного пролога (на март-август) 1496 г., „Studia Historica Europae Orientalis. Исследования по истории Восточной Эвропы”, вып. 3, 2010.

Сава Хиландараи. Историја манастира Хиландара, Београд 1997. 
Срезневский И. И., Материаль для словаря древние-русского языка по письменным памятникам, Санкт-Петербург 1903.

Соловјев А., Св. Сава и Руси, „Српски Кюижевни Гласник. Нова серия”, т. XXXXIV, Београд 1935, № 3.

Стефова Л., Супрасълски сборник, [в:] Кирило-Методиевска енциклопедия, ред. Л. Грашева, т. III, София 2003.

Tachiaos A. E., Le monachisme serbe de Saint Sava et la tradition hésychaste athonite. „Hilandarski sbornik”, vol. I, Beograd 1966.

Тахиос А. Е., Улога светога Саве у оквиру словенске книжевне делатности на Светој Гори, „Мећународни научни скуп Сава Немањић Свети Сава. Историја и предање. Децембар 1976", Београд 1979.

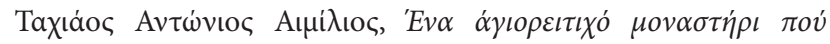

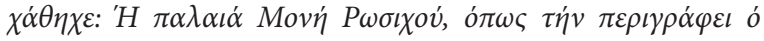

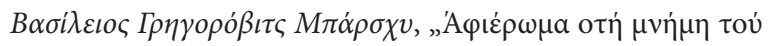

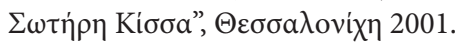

Темчин С. Ю., Бытование древнеболгарского Супрасльского сборника в Великом княжестве Литовском в XVI-XVII веках: новые данные, [w:] Rediscovery. Bulgarian Codex Supraslienis of 10th century, ed. A. Miltenova, Sofia 2012

Темчин С. Ю., Древнейшие рукописи Супрасльского Благовещенского монастыря (1500-1532 г2.): новые данные, [в:] Современные проблемы археографии: сборник статей по материалам конференции проходивщей в Библиотеке РАН, 25-27 мая 2010 г., Санкт-Петербург 2011.

Темчин С. Ю., О бытовании древнеболгарского Супрасльского сборника в Великом княжестве Литовском в XV-XVI вв., [в:] Этнокультурные и этноязыковые контакты на территории Великого княжества Литовского. Материалы международной научной конферениии, Москва 2006.

Темчин С. Ю., Сколько книг было в Супрасльском Благовещенском монастыре в 1532 году, „Здабыткі”, вып. 12, Мінск 2010.

Темчин С. Ю., Рукописи Кимбаровского собрания Супрасльского Благовещенского монастыря (1532-1557 22.), „Knygotyra”, t. LIV, Vilnius 2010, s. 173-180;

Тодоров Н., Балканският град XV-XIX век. Соиално-икономическо и демографско развитие, София 1972.

Тихомиров М. Н., Исторические связи русского народа с южными славянами с древнейших времен до половины XVII в., „Славянский сбобор”, Москва 1947.
Турилов А. А., Антоний Супрасльский, „Православная энциклопедия", т. 2. Москва 2000.

Турилов А. А., Церковно-учительная деятельность Иосифа II, „Православная энциклопедия”, т. XXVI, Москва 2011.

Турилов А. А., Иоанн Серрский, „Православная энциклопедия", т. XXIV, Москва 2010.

Турилов А. А., К истории Стишного Пролога на Руси, „Древняя Русь. Вопросы Медиевистики", нр. 1 (23), март 2006.

Турилов А. А., Южнославянские памятники в титературе и книжности Литовской и Московской Руси XV- первой половины XVI в.; парадоксы истории и географии культурных связей, „Славянский Альманах 2000”, Москва 2001.

Турилов А. А., Житие преподобномученика Антония Супрасльского и славянские жития балканских новомучеников XVI в. (к постановке проблемы), „Hagiographia Slavica”, ed. Herausg. von J. Reinhart, München-Berlin-Wien 2013, (Wiener Slawistischer Almanach. Sonderband”. Bd. 82).

Турилов А. А., Хр. Темелски, Георгий Новый Кратовский, „Православная энциклопедия” т. ХІ, Москва 2006.

Чистякова М. В., Текстологические особенности стишного пролога ГИМ, Увар. 56. - „Kalbotyra 55(2). Slavistica Vilnensis 2010", Vilnius 2010.

Чистякова М. В., Текстология вильнюсских рукописных Прологов, Vilnius 2009.

Щавиская Л. Л., Лабынцев Ю. А., Литература белорусов Польши XV-XIX вв., Минск 2003.

Щавиская Л. Л., Литературная культура белорусов Подляшья XV-XIX вв., Книжые собрания Супрасльского Благовещенского монастьря, Минск 1998.

Щапов Я. Н. , Восточнославянские и южнославянские рукописные книги в собраниях Польской Народной Республи$\kappa и$, Москва 1976.

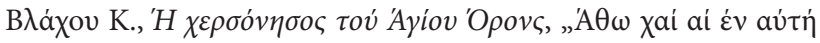

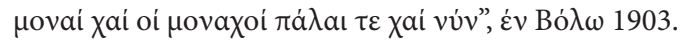

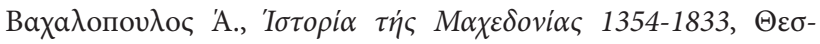

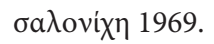

Vaporis N. M., Witnesess for Christ. Orthodox Christian Neomartyrs of the Ottoman Period 1437-1860, Crestwood, New York 2000.

Wydanie okolicznościowe żywotu świętego z ikoną św. Antoniego Supraskiego, Supraśl 2007.

Живојиновиђ М., Светогорске келије и пиргови у средюем веку, Београд 1972. 
ISSN 1508-7719

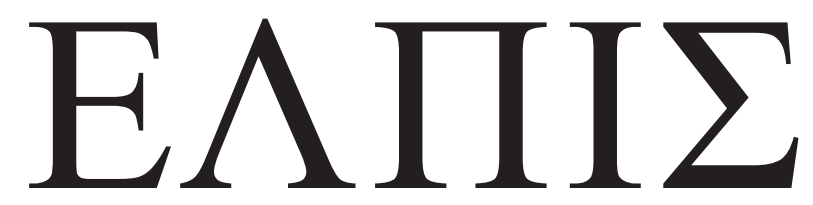

CZASOPISMO TEOLOGICZNE KATEDRY TEOLOGII PRAWOSŁAWNEJ UNIWERSYTETU W BIAŁYMSTOKU

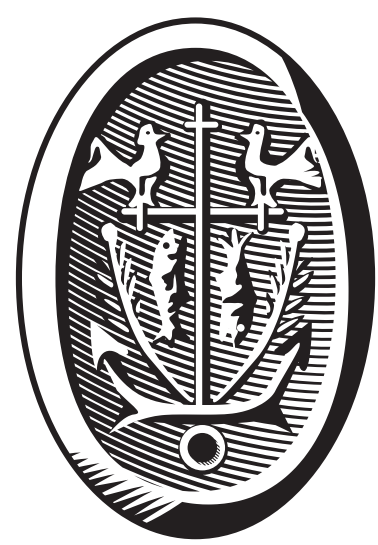

ADRES REDAKCJI

15-097 Białystok, ul. M. Skłodowskiej-Curie 14 tel. 85 745-77-80, e-mail: redakcja@elpis.edu.pl www.elpis.uwb.edu.pl 